\title{
Empirical Study on the Integrated Management System in Algerian Companies
}

\author{
Samiya Benyettou (D), Megnounif Abdellatif iD \\ RIS AM Laboratory, Civil Engineering Department, Tlemcen University (Algeria) \\ samia_live1@hotmail.fr,abdellatif_megnounif@yahoo.fr
}

Received: September 2017

Accepted: February 2018

\section{Abstract:}

Purpose: The integrated management system concept has been installed recently in Algerian companies. A theoretical model is proposed which is based on a functional analysis of the systemic approach. This model is a cycle of seven requirements (organization context, leadership, planning, support, implementation of operational activities, performance evaluation and improvement), in addition to the inputs and outputs. The purpose of this article is to, empirically, investigate the current status of integrated management system and test its performance in Algerian Companies.

Design/methodology/approach: In order to achieve this objective, a structured questionnaire survey is chosen in this study and sent to the 250 selected companies, only 115 of them have responded among them 65 have already implemented an integrated management system (IMS). These companies have different sizes and activities, and operate across the national territory in Algeria. This study employed both exploratory (EFA) and confirmatory (CFA) techniques in the factor analyses and also, in order to identify the relationships between the theoretical constructs, correlation and stepwise regression analyses were used.

Findings: From the results, the research reflects the status of IMS in Algeria. The findings provide specific actions in order to help to clarify the understanding of the integration process within the Algerian companies which seems have some difficulties to implementing the IMS.

Research limitations/implications: One of the major limitations of this study is the small simple size, which precludes generalization of the findings. This study provides a starting point for further research in developing countries.

Originality/value: This paper offers first key insights into IMS implementation in Algeria. This will encourage many local organizations as well as some others in developed countries to adopt the proposed IMS model.

Keywords: Algerian companies, CFA, EFA, integration, management system 


\section{Introduction}

Today, most of the companies are interested in implementing one or more international standards, called ISO systems (International System Organization), and the research conducted in this field is growing rapidly in the case of quality management systems (Georgiev \& Georgiev, 2015), environmental management system (Miguel \& Martins, 2015; Puvanasvaran, Tian, Suresh \& Muhamad, 2012) or other systems.

Over the past 15 years, when ISO 14001 was published, the concept of integrated management system is emerged in the organization management. It was one of the major requirements for organization to ensure survival, cost effectiveness and hereby achieving a framework for decisions complying with corporate policies and strategy (Dahlin \& Isaksson, 2017). It is a set of related processes that share information about human, financial and infrastructural resources in order to achieve preset objectives, while focusing on the requirements of all stakeholders (Willborn, 1998; Karapetrovic \& Jonker, 2003). This means that there is a harmonization and alignment with the strategies and operations of the organization (Garvin, 1991).

The Organizations are increasingly resorting to the implementation and integration of several management systems in order to benefit from certain advantages (Domingues, Sampaio \& Arezes, 2017), such as the reduction of risks and improvement of internal and external efficiency (Olaru, Maier, Nicoară \& Maier, 2014); reduction of costs, duplication of policies and procedure (Rocha, Searcy \& Karapetrovic 2007); creation of synergies and improvement in employees (Khanna, Laroiya \& Sharma, 2010; Simon, Bernardo, Karapetrovic \& Casadesús, 2011), reduction in documentation (Beckmerhagen, Berg, Karapetrovic \& Wilborn 2003; Karapetrovic \& Jonker, 2003; Karapetrovic, 2002; Simon, Karapetrovic \& Casadesús, 2012; Zeng, Shi \& Lou, 2007; Almeida, Domingues \& Sampaio, 2014; Mustapha, Manan \& Wan Alwi, 2017) and man power for document controller (Mustapha et al., 2017), optimization of resources (Muehlen, 2004; Salomone, 2008) and the increase in the management system effectiveness and efficiency (Almeida et al., 2014; Bernardo, Gotzamani, Vouzas \& Casadesus, 2016). In parallel, there are some obstacles in implementing the integrated management system (IMS), that each organization must avoid such as the lack of resources (Abad, Cabrera \& Medina, 2016; Asif, Fisscher, de Bruijn \& Pagell, 2010; Gianni, Gotzamani \& Vouzas, 2017; Simon et al., 2011), employee motivation (Simon et al., 2012; Gianni \& Gotzamani, 2015), top management and staff involvement (Abad et al., 2016), the low organizational commitment, insufficient training, counterproductive attitudes (Simon, 2012), the lack of integration guidelines and management commitment, (Gianni \& Gotzamani, 2015; Moumen \& El Aoufir, 2017), the demand for training and cultural change, the lack of skilled auditors and consultants, the inadequate audit approaches and the deficiency in human as well as other resources (Gianni \& Gotzamani, 2015; López-Fresno, 2010; Simon, Karapetrovic \& Casadesús, 2014), the lack of support and collaboration between departments (Moumen \& El Aoufir, 2017; Rebelo, Santos \& Silva, 2014a,b). Finally, Dahlin has confirmed that most of the models proposed in the literature concerning the ISM are based on the already existing management systems within an organization, an approach called the inside-outside approach, (Dahlin \& Isaksson, 2017).

There are currently several integration methods pushing organizations to choose among various implementation strategies (Ahsen \& Funck, 2001; Asif, de Bruijn, Fisscher, Searcy \& Steenhuis, 2009; Beckmerhagen et al, 2003; Karapetrovic \& Jonker, 2003; Zeng, Lou \& Tam, 2006). The compatibility between standards is the first step in the integration process, an idea supported by several authors, and was defined in the guidelines for integration of management systems published in a handbook by ISO in 2008. In 2015, ISO has changed the approach and developed the philosophy of high level structure (HLS) to increase the compatibility with an identical core requirement. The HLS has an identical text, and the good way to tell upon reading a management system standard is to change the discipline word(s) (e.g. read "environment" instead of "quality") and see if the requirement is still meaningful (Directives 2013). Generally, the degree of compatibility has increased with the use of HLS of ISO9001 and ISO14001 but it was low with other standards like OHSAS18001, ISO22000,...A very few studies was done to generalize the use of the HLS principle in integrating more standards (Ezzat, Bahi \& Nasreldeen, 2017).

The objective of the present work is to empirically test a theoretical proposed model and understand the status of integrated management systems (ISM) implemented in Algerian organizations; the proposed system is based on a structure of seven (07) items (organization context, leadership, planning, support, implementation of operational 
activities, performance evaluation and improvement). In order to have a harmonious system, some relationships are assumed to exist between these functions, which will increase the intensity of the process and also produce more value. These relationships are analyzed by the APTE (application to business techniques) method, to define the system in its basic and sub functions related to the delivery of the product/service, satisfying the stakeholders' requirements.

The proposed model was empirically tested by administering a structured questionnaire survey. The data was gathered over of period of 6 months from companies operating in Algeria. Exploratory and confirmatory analysis procedures with multiple regression analysis were employed in order, firstly, to develop summated scales for measuring the constructs of the proposed model; and secondly, to identify the relationship between these constructs. The SPSS and AMOS softwares were used for this purpose.

\section{Theoretical Framework}

A theoretical model is proposed based on models of (Bernardo \& Casadesus, 2009; Karapetrovic, 2002; Karapetrovic \& Jonker, 2003; Rocha et al., 2007; Wilkinson \& Dale, 2000; Willborn, 1998). The systemic approach was used, which can link the process and the PDCA approaches, and bring them under one roof (Karapetrovic, 2002). Researches perceived IMS as a process that receives input from its context and produces organization performance as output. The input model contained a set of factors. The classification of these factors varies from one author to another taking into account varied needs of stakeholders, while neglecting combinations to every need of stakeholder as well as other new elements adapted to the local context for full integration. The IMS process handling management of company is associated with a set of sub-functions. Several studies have identified policy, planning, deployment, acquisition and evaluation as elements of process of IMS (Beckmerhagen et al., 2003; Zeng et al., 2007) on using a different approach.

To conduct this research, a functional analysis was performed to define the internal and external relationships and facilitate the implementation of the system. The functional analysis is an approach that fully describes the functions of the system and their relationships that are systematically characterized, classified and evaluated. This approach is difficult because it must meet the expected theoretical requirements and also face reality, but this difficulty remains an asset since the purpose sought is an interpretative method for the functional analysis of the IMS.

The APTE method is used to give an initial definition of IMS, for its purpose and its relationship with the environment. This system relies on the data of standards to manage the objectives of each process in accordance with the organization's strategy.

Therefore, the main issue in the Integrated Management System (IMS) is to satisfy all the interested parties, first of all defining and understanding their requirements which are later transformed into the main objectives of the organization. In our approach, the different entrants' management systems are supposed to have a strong bond between them. When each system is taken separately, it is found that it is based on one or two elements of the interested part, and tries to satisfy them.

The theoretical model includes three parts: IMS factors (inputs), IMS functions (process), and product and satisfaction of stakeholders (outputs). The IMS factors are based on two factors: the context of organization and requirement of interested parties. Each organization must define and follow an internal and external issue leading to the determination of the needs of stakeholders which are increasing and where their interests are seen as important and integral to the organization's mission (Amarah, 2015). The IMS process is structured based on literature reviews that determine the role of leadership, planning the objectives, deployment and support by the resource, realization of the strategy, evaluation of the performance and improvement of the strategy. Table 1 illustrates the description of IMS functions. Finally, the IMS output is structured based on performance organization. 


\begin{tabular}{|c|c|c|}
\hline Functions & Description & Sub-functions \\
\hline $\begin{array}{l}\text { Context of the } \\
\text { organization }\end{array}$ & $\begin{array}{l}\text { determine the internal and external issues } \\
\text { related to IMS system }\end{array}$ & $\begin{array}{l}\text { - Internal issue } \\
\text { - External issue }\end{array}$ \\
\hline $\begin{array}{l}\text { Stakeholder } \\
\text { requirements }\end{array}$ & Determine the requirements & - Analyze requirements of stakeholders \\
\hline Leadership & $\begin{array}{l}\text { Consists of leading a group of people to } \\
\text { accomplish a task or to reach an objective } \\
\text { through various means }\end{array}$ & $\begin{array}{l}\text { - Leadership and commitment, } \\
\text { - Communication of IMS } \\
\text { - Roles, responsibilities and authorities }\end{array}$ \\
\hline Planning & $\begin{array}{l}\text { The IMS planning involves determining } \\
\text { specific goals and implementing proper } \\
\text { means to achieve them on time. }\end{array}$ & $\begin{array}{l}\text { - Implementation of actions against risks, } \\
\text { - Policy } \\
\text { - Planning of change. }\end{array}$ \\
\hline Support & Human resource, Material and infrastructure. & $\begin{array}{l}\text { - Identification of the resource } \\
\text { - The needs for internal and external communication, } \\
\text { - Documenting information. }\end{array}$ \\
\hline $\begin{array}{l}\text { Realization of } \\
\text { operational } \\
\text { activities }\end{array}$ & $\begin{array}{l}\text { Producing the goods or providing the } \\
\text { services offered by the organization. }\end{array}$ & $\begin{array}{l}\text { - Operational planning and control, } \\
\text { - Requirements for goods and services, } \\
\text { - Design and product development } \\
\text { - Control of processes } \\
\text { - Production, } \\
\text { - Release of product }\end{array}$ \\
\hline $\begin{array}{l}\text { Evaluation } \\
\text { performance }\end{array}$ & $\begin{array}{l}\text { It is a function allowing the control and } \\
\text { management of an organization's efficiency. }\end{array}$ & $\begin{array}{l}\text { - Evaluation, } \\
\text { - Internal audit } \\
\text { - Management review }\end{array}$ \\
\hline Improvement & $\begin{array}{l}\text { Recommendations, concerns, and ways to } \\
\text { improve each step in the continuous } \\
\text { improvement system }\end{array}$ & $\begin{array}{l}\text { - Non-conforming and corrective action, and } \\
\text { - Continuous improvement. }\end{array}$ \\
\hline $\begin{array}{l}\text { Organization } \\
\text { Performance }\end{array}$ & $\begin{array}{l}\text { An analysis of a company's performance as } \\
\text { compared to goals and objectives. }\end{array}$ & $\begin{array}{l}\text { - Financial } \\
\text { - Stakeholders analysis } \\
\text { - Internal analysis }\end{array}$ \\
\hline
\end{tabular}

Table 1. Description of the IMS functions by APTE method

\section{The Hypotheses of the IMS}

A diversity of model was proposed by researchers in the field of IMS, each of them proposed an integration cycle, but the majority took the process cycle (planning, operational, evaluation, improvement) as a basis for their system. Our system has added to the cycle, two factors: the leadership that directs it, and the resources that are the executors of the system's leaders. The more one takes into consideration the context of organization as input and adding them to the stakeholder requirement. For these reasons, we have proposed six hypotheses for testing our model. (The overall structure of this model is illustrated in Figure 1).

Hypothesis 1 (H1): The leadership uses the information of the context in elaborating the objectives.

The "leadership" receives its inputs from the definition and the understanding of the requirements of the interested parties and from the organization and its context to turn them into actions that are necessary for the planning. The challenge in this function is using the organization context as input of the system instead of stakeholders needs.

Hypothesis 2 (H2): The objectives elaborated by the leadership are forwarded in a planning process.

The planning data must be collected from the "leadership" outputs. The IMS planning involves determining specific goals and implementing proper means to achieve them on time. 
Hypothesis 3 (H3): the support transforms plans into tasks to achieve them.

For the system to be properly implemented, it must be supported along its life cycle. Human and material resources are required for a successful system. Human resources should be managed, trained and motivated for a good implementation. Material or infrastructural resources, such as buildings, equipments must be available in the organization.

Hypothesis 4 (H4): the realization of operational activities function transforms the plan into product with the support function.

Operations management includes the management of people, processes, technology and other resources who produce goods and services. An operation is responsible for producing the goods or providing the services offered by the organization.

Hypothesis $\mathbf{5}$ (H5): the performance evaluation has a relationship between realization of performance evaluation and satisfaction of interested parties.

Performance management is a function that allows the control management of an organization's efficiency by means of Key Performance Indicators which can be applied to profit. Mathé and Chagué (1999) defined performance measurement using two criteria, named effectiveness and efficiency (Mathé \& Chagué, 1999).

Hypothesis $6(\mathbf{H 6})$ : the improvement function has a relationship between performance evaluation and context organization.

Continuous improvement allows the organization to generate more profits for long-term. It is a philosophy of Deming, improvement initiatives that increase successes and reduce failures" (Bhuiyan \& Baghel, 2005).

Hypothesis 7 (H7): The IMS is a strategy to implement multiple standards and ensure the performance of the organization.

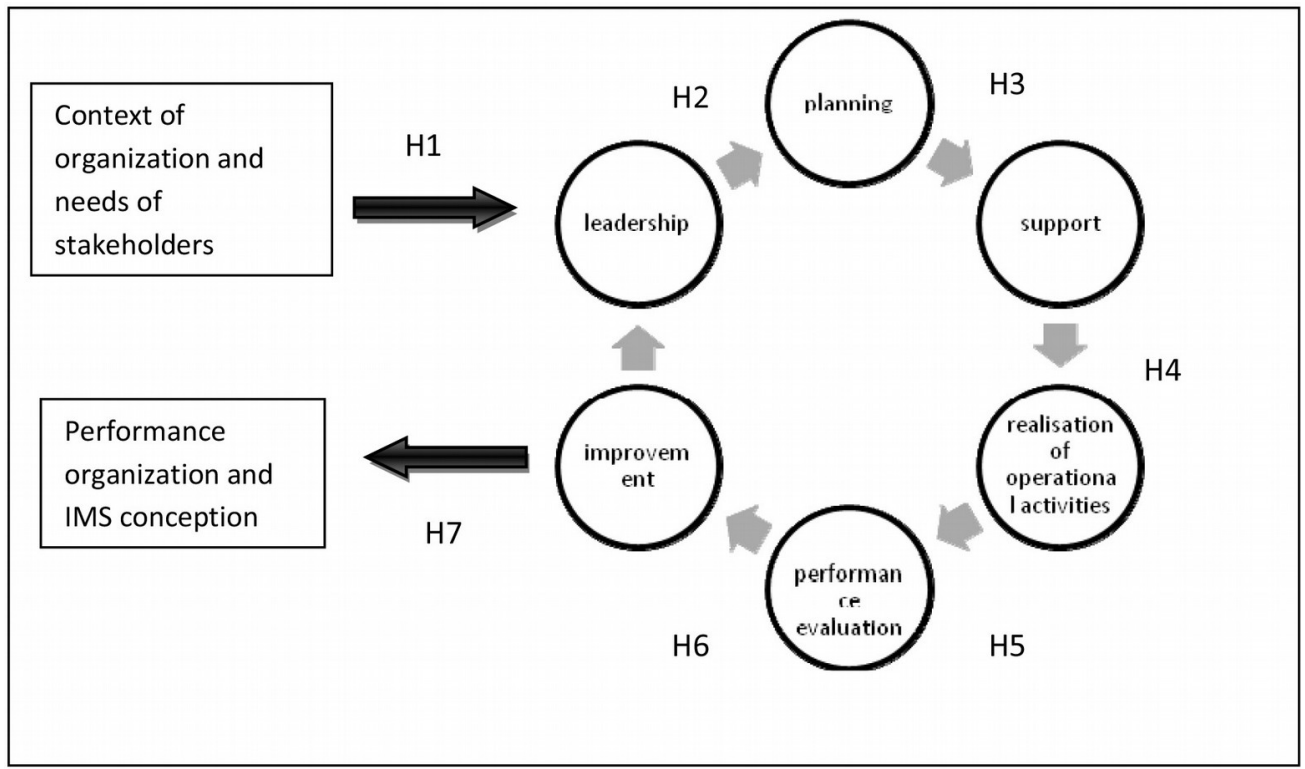

Figure 1. Proposed integrated management system (IMS) model

\section{Methodology}

A questionnaire survey was conducted with the collaboration of Algerian companies to test the previous hypotheses. The questionnaire designed to reach mainly the managers, was divided into four main sections: The first section includes general information about the responding organization (size, type of activity, region) and about the implemented systems and the time of the implementation (Bernardo \& Casadesus, 2009; Isaksson \& Garvare, 2003; Kafel, 2016), the second focuses on the context of the organization and the requirements of the interested parties. The third section includes statements to reflect on IMS functions adopted and implemented by 
companies and the last section of the survey lists the indicators of the satisfaction of the interested parties. The measurement items of the questionnaire were based on relevant literature. A five-point Likert-type scale, ranging from 1 (strongly disagree) to 5 (strongly agree), is used to measure the research variables. The questionnaire is composed of a total of 78 statements (items). A total of 300 questionnaires were distributed to selected Algerian certified companies but only 115 responded where 65 of them have implemented at list two different systems certified by external auditors like QMI Canada, Bureau Veritas, AFAQ and AFNOR. The data were gathered over a period of 6 months. For enhanced consistency, this work was carried out with methodology for examine all the process of integration in Algerian companies. Within the aforementioned research framework the steps followed are depicted in Figure 2.

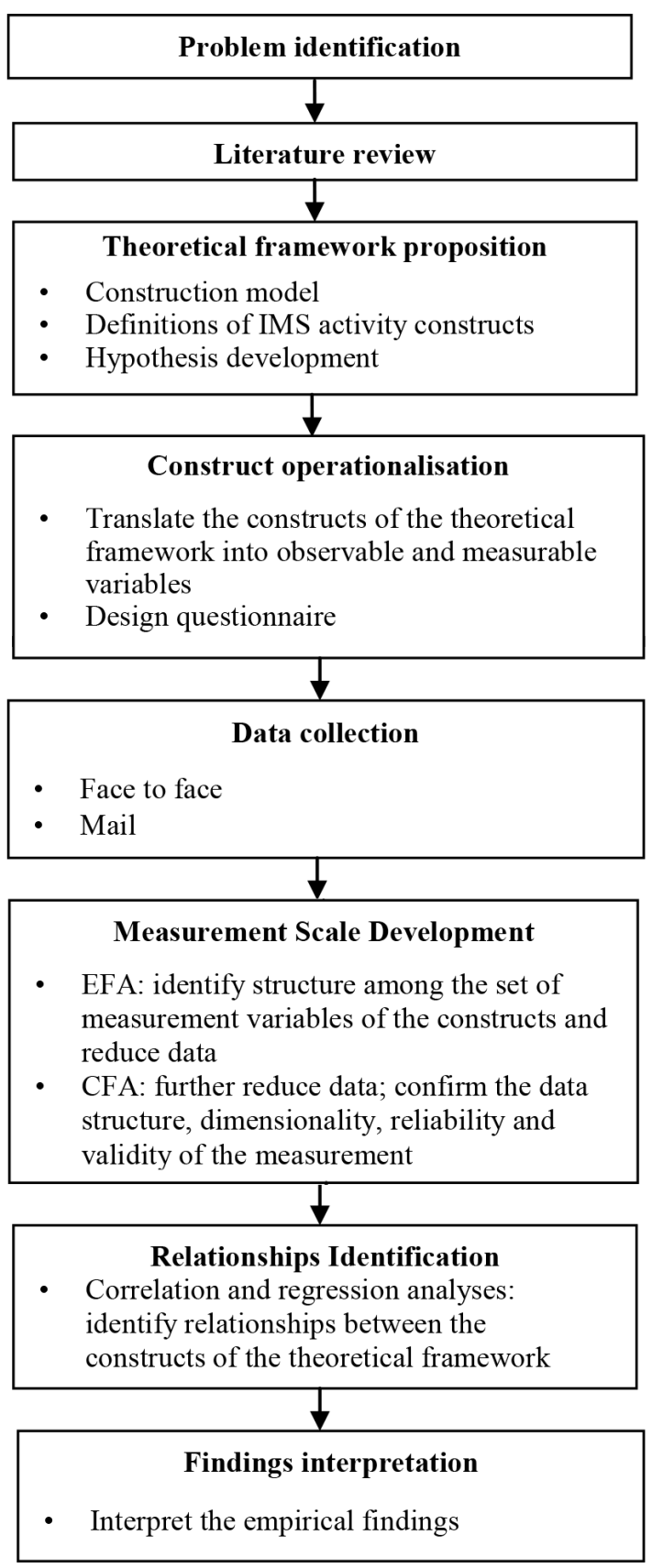

Figure 2. Strategy adopted in this research 


\section{Data Analysis}

The questionnaire has nine constructs in the proposed theoretical framework, viz. CO: organization context, EP: requirement of interested parties. FL: leadership, FP: planning, FS: support, FO: operational activities, FE: performance evaluation, FA: improvement, FSPP: satisfaction of interested parties and performance organization. Table 2 summarizes the general information about the respondent companies.

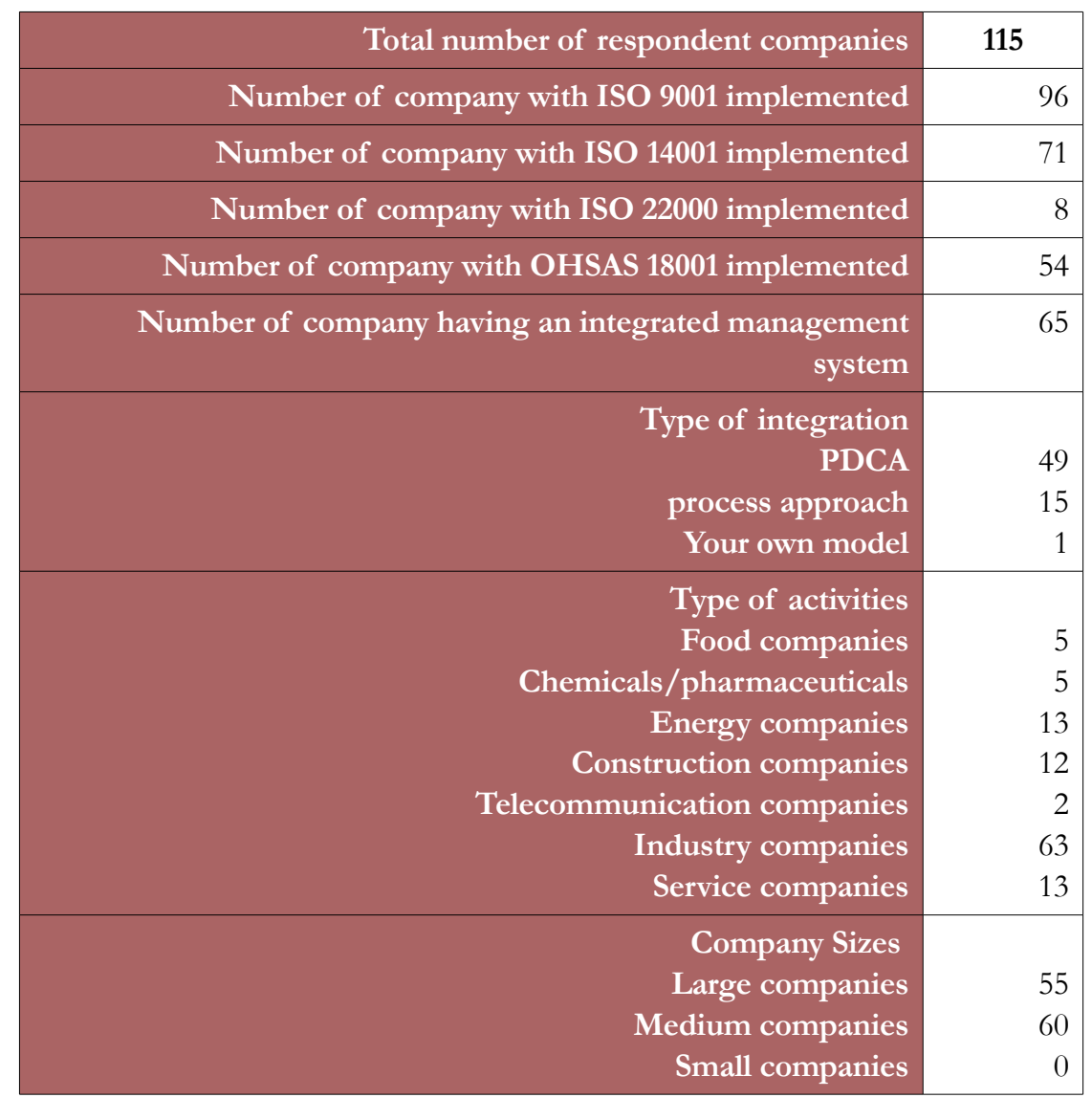

Table 2. General information of respondents

It is noted from these findings that a great majority of the companies having implemented more than one standard, has followed the first strategy of Karapetrovic and Jonker (2003), implementing first QMS, then the other systems), and used, also the PDCA approach. No more than one feedback questionnaire was chosen from each company to avoid bias in the data and only those obtained from the top managers were kept for the data analysis. So the majority of the respondents, at the time of the survey, were well educated, experienced, with a high career and having a very good knowledge about their company's operations, so we considered that the responses were a good representation of the population.

\subsection{Exploratory Factor Analysis}

In the first step, we perform an Exploratory Factor Analysis (EFA) in order to gather the variables into latent constructs valid for interpretation and further analysis. We seek to unite the variables related to each construct. EFA was adopted to identify the structure among the set of measurement variables for each construct and also for data reduction (Chen, 2007). Nine constructs were operated, based on the selected measurement variables for each construct of the theoretical framework. Table 3 presents the results of the EFA analysis with a value of KMO greater than 0.600 , Bartlett's tests of sphericity large and significant at the 0.0005 level, and all anti image correlation values larger than 0.500 (Chen, 2007). The factorability was, therefore, upheld for these nine factor analysis scenarios. Noting, also, that the reliability Cronbach's alpha coefficient was greater than 0.7. 


\begin{tabular}{|c|r|r|r|}
\hline Construct & KMO & Bartlett's test of sphericity & \multicolumn{1}{c|}{ Anti image } \\
\hline CO & 0.837 & 752.823 & $0.010-0.894$ \\
\hline EP & 0.733 & 435.017 & $0.001-1.000$ \\
\hline FL & 0.8 & 278.130 & $0.008-0.805$ \\
\hline FP & 0.716 & 278.130 & $0.28-0.819$ \\
\hline FS & 0.603 & 811.701 & $0.20-0.863$ \\
\hline FO & 0.786 & 680.585 & $0.082-0.805$ \\
\hline FE & 0.618 & 218.355 & $0.016-0.873$ \\
\hline FA & 0.612 & 146.145 & $0.015-0.711$ \\
\hline FSPP & 0.631 & 904.031 & $0.011-0.804$ \\
\hline
\end{tabular}

Table 3. Factorability of the EFA

The results for the EFA identified factors of each construct are presented in Tables 4 through to 12. Since these factors are based on a combination of the literature review and previous empirical studies, these scales were considered to have "face validity" (Hair, Anderson, Tatham \& Black, 1998). With the sample of 65, a factor loading of 0.50 and above was considered significant at the 0.05 level, to obtain a power level of $80 \%$ (Hair et al., 1998); thus the variables with a factor loading less than 0.50 were eliminated (Chen, 2007). In order to determine the number of factors to retain, we use two criterions: Kaiser's criterion where only factors with an eigenvalue of 1.0 and greater were retained and Catell's scree test where only the factors above the "elbow" of the plotting eigenvalues were retained (Pallant, 2001: page 183).

The structure of the data for construct $\mathrm{CO}$ was perceived to have two dimensions (external and internal issues). Each of the two dimensions was expected to be represented by several variables derived in prior empirical studies. The initial principal component analysis assured that the construct $\mathrm{CO}$ has two components having eigenvalues greater than 1.0; nevertheless, factor loadings of variable CO2 and CO5 were lower than 0.5 , so they were removed from the analysis. A second analysis was conducted without $\mathrm{CO} 2$ and $\mathrm{CO} 5$ and the obtained result for the $\mathrm{CO}$ construct is given in Table 4. The EFA identified two factors COi and COx; that explained $64.97 \%$ of the variance. Cronbach's alpha coefficient of $\mathrm{CO}$ is 0.869 indicative of very good internal consistency.

\begin{tabular}{|l|r|r|}
\hline \multirow{2}{*}{ Variable } & \multicolumn{2}{c|}{ Rotated component matrix } \\
\cline { 2 - 3 } & Internal issues (COa) & External issues (COb) \\
\hline CO8: Culture of its employees. & $\mathbf{0 . 9 2 5}$ & 0.230 \\
\hline CO10: Performance of its employees. & $\mathbf{0 . 9 1 8}$ & 0.162 \\
\hline CO9: Knowledge of its employees & $\mathbf{0 . 9 1 1}$ & 0.211 \\
\hline CO7: Values of its employees. & $\mathbf{0 . 8 7 7}$ & 0.271 \\
\hline CO1: Market competition & 0.208 & $\mathbf{0 . 8 3 5}$ \\
\hline CO3: Adapt to changes in legal acts & 0.105 & $\mathbf{0 . 8 2 2}$ \\
\hline CO6: Issues arising from the economic environment & 0.307 & $\mathbf{0 . 6 9 1}$ \\
\hline CO4: Issues arising from the cultural environment & 0.237 & $\mathbf{0 . 5 9 4}$ \\
\hline Rotation sum of squared loadings & & 1.560 \\
Eigenvalues & 4.938 & 15.596 \\
Percentage of variance explained $(\%)$ & 49.380 & 64.976 \\
Cumulative percentage of variance explained $(\%)$ & 49.380 & \\
Remove the variable CO2 and CO5 & & \\
\hline Reliability (Cronbach's alpha) $\mathbf{0 . 8 6 9}$ & & \\
\hline
\end{tabular}

Table 4. EFA of the CO construct 
For the EP construct, initially there were 10 variables selected to define the requirement of stakeholders and requirement of system (IMS). The initial principal component EFA analysis revealed three factors: determination of requirement, determination of system information and the most relevant stakeholder of the system. In the subsequent analyses, variable EP3 was removed due to low factor loadings $(<0.5)$. The three factors explained, without EP3, $65.94 \%$ of the variance and the Cronbach's alpha coefficient was 0.804 indicative of very good internal consistency (Kline, 1998).

\begin{tabular}{|c|c|c|c|}
\hline \multirow[b]{2}{*}{ Variables } & \multicolumn{3}{|c|}{ Rotated component matrix } \\
\hline & $\begin{array}{l}\text { The most relevant } \\
\text { stakeholder for the } \\
\text { company (EPb) }\end{array}$ & $\begin{array}{l}\text { Determination of } \\
\text { requirement }(\mathrm{EPa})\end{array}$ & $\begin{array}{l}\text { Determination of } \\
\text { information of } \\
\text { system (EPc) }\end{array}$ \\
\hline $\begin{array}{l}\text { EP5: The most relevant stakeholder for the } \\
\text { company is the SHAREHOLDER }\end{array}$ & 0.898 & 0.184 & 0.010 \\
\hline $\begin{array}{l}\text { EP10: The company complies with the legal and } \\
\text { Algerian regulations }\end{array}$ & 0.897 & 0.045 & 0.135 \\
\hline $\begin{array}{l}\text { EP4: The most relevant stakeholder The company } \\
\text { is the SUPPLIER }\end{array}$ & 0.832 & 0.164 & 0.107 \\
\hline $\begin{array}{l}\text { EP2: The most relevant stakeholder for the } \\
\text { company is leadership }\end{array}$ & 0.116 & 0.793 & 0.032 \\
\hline $\begin{array}{l}\text { EP6: Identifying stakeholder needs is important for } \\
\text { the determination of objectives }\end{array}$ & 0.173 & 0.791 & 0.031 \\
\hline $\begin{array}{l}\text { EP1: The most relevant stakeholder for the } \\
\text { company is the CLIENT }\end{array}$ & 0.000 & 0.680 & 0.449 \\
\hline $\begin{array}{l}\text { EP7: Understanding stakeholder expectations is } \\
\text { important for the determination of objectives }\end{array}$ & 0.012 & 0.581 & 0.553 \\
\hline $\begin{array}{l}\text { EP9: The company has a system for reviewing } \\
\text { information about stakeholders and their } \\
\text { requirements }\end{array}$ & 0.083 & -0.003 & 0.831 \\
\hline $\begin{array}{l}\text { EP8: The company has a surveillance system } \\
\text { information about the Stakeholders and their } \\
\text { requirements }\end{array}$ & 0.150 & 0.313 & 0.710 \\
\hline $\begin{array}{l}\text { Rotation sum of squared loadings } \\
\text { Eigenvalues } \\
\text { Percentage of variance explained (\%) } \\
\text { Cumulative percentage of variance explained (\%) } \\
\text { EP3 variable removed }\end{array}$ & $\begin{array}{r}3.706 \\
37.058 \\
37.058\end{array}$ & $\begin{array}{r}1.867 \\
18.671 \\
55.729\end{array}$ & $\begin{array}{r}1.020 \\
10.214 \\
65.943\end{array}$ \\
\hline
\end{tabular}

Table 5. EFA of the EP construct

The process of IMS is defined by 6 factors (FL, FP, FS, FO, FE, and FA). For the leadership construct (FL), a total of 10 variables were selected to define it. The initial principal component analysis revealed three factors: "FLa: role of leadership" demonstrating the leadership and his commitment; "FLb: policy" where the top manager establishes the IMS policy and the "FLc: roles and responsibilities of organization" where the top manager shall ensure that the responsibilities and authorities are assigned. Based on the output of both the eigenvalue and Catell's scree test variable FL7 was removed due to low factor loading $(<0.5)$. The coefficient of Cronbach's alpha coefficient was 0.786 indicative of good internal consistency. 


\begin{tabular}{|c|c|c|c|}
\hline \multirow[b]{2}{*}{ Variables } & \multicolumn{3}{|c|}{ Rotated component matrix } \\
\hline & $\begin{array}{l}\text { Roles and } \\
\text { responsibilities of } \\
\text { organization (FLc) }\end{array}$ & Policy (FLb) & $\begin{array}{l}\text { Role of leadership } \\
\text { (FLa) }\end{array}$ \\
\hline $\begin{array}{l}\text { FL9: Top management is committed to } \\
\text { stakeholders' orientation }\end{array}$ & 0.877 & 0.00 & 0.124 \\
\hline $\begin{array}{l}\text { FL8: Top management promotes the } \\
\text { improvement, Safety, respect for the environment. }\end{array}$ & 0.833 & 0.091 & 0.117 \\
\hline $\begin{array}{l}\text { FL10: Top management ensures that the } \\
\text { responsibilities and authorities for relevant roles are } \\
\text { allocated and communicated. }\end{array}$ & 0.591 & 0.460 & 0.074 \\
\hline $\begin{array}{l}\text { FL6: The established objectives meet the } \\
\text { Stakeholders' needs }\end{array}$ & 0.038 & 0.713 & 0.149 \\
\hline $\begin{array}{l}\text { FL2: Top management sets clear objectives which } \\
\text { meet the stakeholders' needs. }\end{array}$ & 0.324 & 0.707 & -0.294 \\
\hline $\begin{array}{l}\text { FL4: Top management ensures that resources } \\
\text { required are available in the organization }\end{array}$ & 0.158 & 0.548 & 0.404 \\
\hline $\begin{array}{l}\text { FL5: The established policy and objectives are } \\
\text { compatible with the context and strategic } \\
\text { orientation of the company }\end{array}$ & 0.450 & 0.546 & 0.404 \\
\hline $\begin{array}{l}\text { FL1: Top management assumes its responsibility } \\
\text { towards the implementation of the system } \\
\text { management (standards) }\end{array}$ & 0.084 & 0.041 & 0.821 \\
\hline $\begin{array}{l}\text { FL3: Top management communicates to the } \\
\text { employees the importance of implementing } \\
\text { standards }\end{array}$ & 0.247 & 0.331 & 0.530 \\
\hline $\begin{array}{l}\text { Rotation sum of squared loadings } \\
\text { Eigenvalues } \\
\text { Percentage of variance explained }(\%) \\
\text { Cumulative percentage of variance explained }(\%) \\
\text { FL7 variable removed }\end{array}$ & $\begin{array}{r}3.573 \\
35.733 \\
35.733\end{array}$ & $\begin{array}{r}1.190 \\
11.902 \\
47.635\end{array}$ & $\begin{array}{r}1.028 \\
10.284 \\
57.919\end{array}$ \\
\hline
\end{tabular}

Table 6. EFA of the FL construct

Initially there were a total of 6 variables selected to define planning construct FP. The first principal component analysis made up two factors: risk and determination of plan. In the subsequent analyses the item FL6 was removed due to low factor loadings $(<0.5)$. The Cronbach's alpha coefficient was 0.707 indicative of good internal consistency.

The support construct (FS) was composed of 10 variables, the initial EFA analysis was made to regroup the variables into two factors: determination of support, representing the determination of the resources needed for the establishment, implementation, maintenance and continual improvement of IMS process and control of document information, representing the documented information necessary for the effectiveness of the IMS system. The variables FS1 and FS4 with low loadings $(<0.5)$ were removed and we obtained 64.785 value of cumulative variation and a Cronbach's alpha coefficient of 0.886 . 


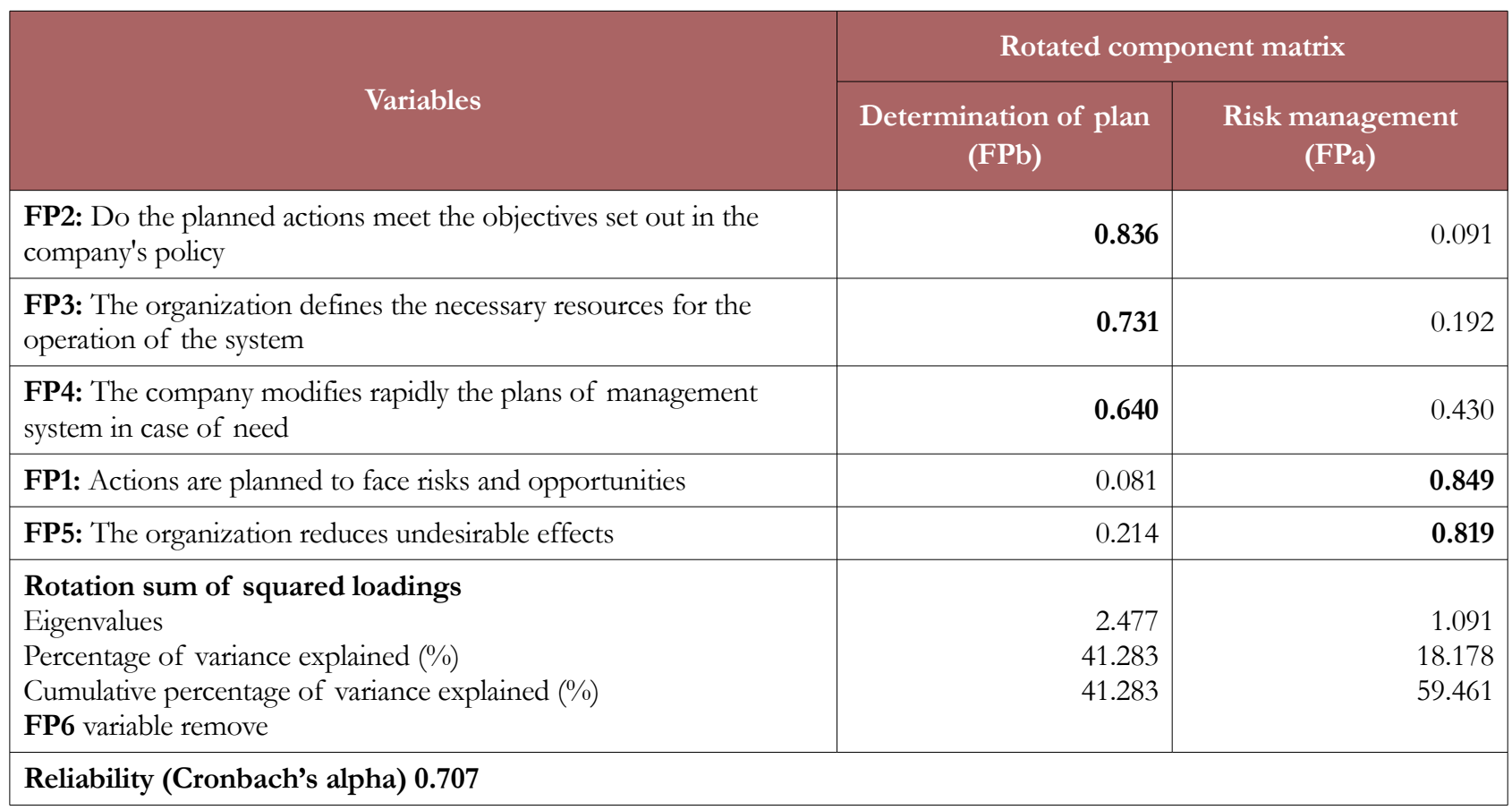

Table 7. EFA of the FP construct

\begin{tabular}{|c|c|c|}
\hline \multirow[b]{2}{*}{ Variables } & \multicolumn{2}{|c|}{ Rotated component matrix } \\
\hline & $\begin{array}{l}\text { Determination of } \\
\text { support (FSa) }\end{array}$ & $\begin{array}{l}\text { Control of document } \\
\text { (FSb) }\end{array}$ \\
\hline FS3: The company has a motivating staff policy & 0.910 & 0.003 \\
\hline $\begin{array}{l}\text { FS2: The company offers training programs to improve the } \\
\text { knowledge of its employees }\end{array}$ & 0.888 & 0.047 \\
\hline $\begin{array}{l}\text { FS5: The company ensures that its employees are aware of the } \\
\text { policy and objectives. }\end{array}$ & 0.786 & 0.351 \\
\hline FS6: Employees are informed of the policy and of the changes & 0.722 & 0.375 \\
\hline FS8: Information on the Management are available and are used & 0.161 & 0.870 \\
\hline FS10: Information flows rapidly in the company & 0.213 & 0.842 \\
\hline FS9: The company makes an update after each change & 0.95 & 0.802 \\
\hline FS7: Management system information are recorded in documents & 0.396 & 0.744 \\
\hline $\begin{array}{l}\text { Rotation sum of squared loadings } \\
\text { Eigenvalues } \\
\text { Percentage of variance explained }(\%) \\
\text { Cumulative percentage of variance explained }(\%) \\
\text { FS1 and FS4 variables removed }\end{array}$ & $\begin{array}{r}4.696 \\
46.955 \\
46.955\end{array}$ & $\begin{array}{r}1.783 \\
17.830 \\
64.785\end{array}$ \\
\hline
\end{tabular}

Table 8. EFA of the FS construct

A total of 15 variables were defined to select the operational activities (FO). The initial principal component analysis revealed the presence of three factors with eigenvalues exceeding 1 , explaining $56.466 \%$ of the total variance, namely, "FOa: design of production" representing the requirements for the design and development process that is appropriate to ensure the subsequent provision of products and services. "FOb: production" representing the characteristics of the products to be produced; the results to be achieved and the availability of resources. "FOc: release of production" representing the plan arrangements, at appropriate stages, to verify that the 
product and service requirements have been met. The variables FO3, FO12 and FO13 were removed on, subsequently due to low factor loading $(<0.5)$. The final Cronbach's alpha obtained was 0.802 .

\begin{tabular}{|c|c|c|c|}
\hline \multirow[b]{2}{*}{ Variables } & \multicolumn{3}{|c|}{ Rotated component matrix } \\
\hline & Production (FOb) & $\begin{array}{l}\text { Design of } \\
\text { production }(\mathrm{FOa})\end{array}$ & $\begin{array}{l}\text { Release of } \\
\text { production }(\mathrm{FOc})\end{array}$ \\
\hline $\begin{array}{l}\text { FO7: The company controls the implementation of } \\
\text { production }\end{array}$ & 0.856 & 0.107 & 0.107 \\
\hline $\begin{array}{l}\text { FO8: The company has a system of identification, } \\
\text { traceability of compliance Products / services }\end{array}$ & 0.846 & 0.310 & 0.025 \\
\hline $\begin{array}{l}\text { FO10: The company complies with the } \\
\text { requirements after delivery of the product / service }\end{array}$ & 0.825 & 0.277 & 0.058 \\
\hline $\begin{array}{l}\text { FO9: The company respects the ownership of the } \\
\text { clients and the external service providers. }\end{array}$ & 0.764 & 0.002 & 0.011 \\
\hline $\begin{array}{l}\text { FO1: The company plans, implements and manages } \\
\text { the operational processes to satisfy the } \\
\text { requirements. }\end{array}$ & 0.074 & 0.832 & 0.105 \\
\hline $\begin{array}{l}\text { FO5: The company establishes, implements and } \\
\text { maintains a process of designing and developing } \\
\text { Product / Service }\end{array}$ & 0.230 & 0.755 & 0.071 \\
\hline $\begin{array}{l}\text { FO6: The company has a conformity of processes } \\
\text { and products / services provided by an external } \\
\text { service provider }\end{array}$ & 0.142 & 0.632 & 0.016 \\
\hline $\begin{array}{l}\text { FO2: The company establishes continuous } \\
\text { communication with customers }\end{array}$ & 0.032 & 0.600 & 0.200 \\
\hline $\begin{array}{l}\text { FO4: The raw material of the product / service is } \\
\text { monitored and complies with standard regulations }\end{array}$ & 0.378 & 0.556 & -0.069 \\
\hline $\begin{array}{l}\text { FO11: The company has a system to review and } \\
\text { control the changes relating to the production }\end{array}$ & 0.322 & 0.369 & 0.862 \\
\hline FO15: The company has an after sales service & 0.102 & 0.065 & 0.858 \\
\hline $\begin{array}{l}\text { FO14: The company treats and corrects the non- } \\
\text { complying products / services }\end{array}$ & -0.035 & 0.020 & 0.812 \\
\hline $\begin{array}{l}\text { Rotation sum of squared loadings } \\
\text { Eigenvalues } \\
\text { Percentage of variance explained }(\%) \\
\text { Cumulative percentage of variance explained (\%) } \\
\text { FO3, FO12 and FO13 variables removed }\end{array}$ & $\begin{array}{r}4.602 \\
30.680 \\
30.680\end{array}$ & $\begin{array}{r}2.320 \\
15.466 \\
46.146\end{array}$ & $\begin{array}{r}1.548 \\
10.320 \\
56.466\end{array}$ \\
\hline
\end{tabular}

Table 9. EFA of the FO construct

Five variables were first selected to explain performance evaluation (FE). The initial EFA analysis revealed two factors with eigenvalues exceeding 1 and explaining $76.41 \%$ of total variance: "FEa: analysis" representing the evaluation of the performance and the effectiveness of the IMS; "FEb: management review" representing the review, at planned intervals, of the organization's IMS system to ensure its continuous suitability, effectiveness and alignment with the strategic direction of the organization. All the five variables were kept and the Cronbach's alpha was 0.721 . 


\begin{tabular}{|c|c|c|}
\hline \multirow[b]{2}{*}{ Variables } & \multicolumn{2}{|c|}{ Rotated component matrix } \\
\hline & $\begin{array}{l}\text { Analyze } \\
\text { (FEa) }\end{array}$ & $\begin{array}{l}\text { Management review } \\
\text { (FEb) }\end{array}$ \\
\hline $\begin{array}{l}\text { FE2: The company has a monitoring and measuring system of the } \\
\text { level of customer satisfaction }\end{array}$ & 0.934 & 0.135 \\
\hline $\begin{array}{l}\text { FE3: The company has a system of analysis and evaluation of data } \\
\text { from the monitoring and measurement system }\end{array}$ & 0.872 & 0.075 \\
\hline $\begin{array}{l}\text { FE1: The company has a monitoring and measurement system of the } \\
\text { product / service }\end{array}$ & 0.816 & 0.053 \\
\hline FE4: The organization establishes internal audits at planned intervals. & 0.088 & 0.861 \\
\hline FE5: The company programs management review at planned intervals. & 0.080 & 0.860 \\
\hline $\begin{array}{l}\text { Rotation sum of squared loadings } \\
\text { Eigenvalues } \\
\text { Percentage of variance explained }(\%) \\
\text { Cumulative percentage of variance explained }(\%) \\
\text { No variable removed }\end{array}$ & $\begin{array}{r}2.463 \\
49.265 \\
49.265\end{array}$ & $\begin{array}{r}1.358 \\
27.153 \\
76.418\end{array}$ \\
\hline
\end{tabular}

Table 10. EFA of the FE construct

The improvement construct (FA) was defined by six variables. The EFA analysis was conducted to concept two factors with eigenvalues exceeding 1 and $60.213 \%$ of total variance: "FAa: non conforming product" where the organization shall determine and eliminate the causes of the non-conforming product and FAb: continual improvement" where the organization shall continually improve the effectiveness of the IMS system. The Cronbach was 0.7 .

\begin{tabular}{|c|c|c|}
\hline \multirow[b]{2}{*}{ Variables } & \multicolumn{2}{|c|}{ Rotated component matrix } \\
\hline & $\begin{array}{l}\text { Non conforming } \\
\text { product (FAa) }\end{array}$ & $\begin{array}{l}\text { Continual } \\
\text { improvement (FAb) }\end{array}$ \\
\hline $\begin{array}{l}\text { FA4: The company analyzes the causes of nonconformity of } \\
\text { product / service }\end{array}$ & 0.907 & 0.079 \\
\hline $\begin{array}{l}\text { FA5: The company records information on the type of non- } \\
\text { conformity and the results of any corrective action }\end{array}$ & 0.835 & 0.095 \\
\hline $\begin{array}{l}\text { FA3: The company has a cell customer claims for non-conformity of } \\
\text { products / services }\end{array}$ & 0.568 & 0.304 \\
\hline $\begin{array}{l}\text { FA2: The company has a system of correction, prevention and } \\
\text { reduction of undesirable effects }\end{array}$ & 0.090 & 0.791 \\
\hline $\begin{array}{l}\text { FA1: The company improves the product to meet future requirements } \\
\text { of stakeholders }\end{array}$ & 0.182 & 0.784 \\
\hline $\begin{array}{l}\text { FA6: The company continuously improves performance of the } \\
\text { company }\end{array}$ & 0.117 & 0.604 \\
\hline $\begin{array}{l}\text { Rotation sum of squared loadings } \\
\text { Eigenvalues } \\
\text { Percentage of variance explained }(\%) \\
\text { Cumulative percentage of variance explained }(\%) \\
\text { No variable removed }\end{array}$ & $\begin{array}{r}2.422 \\
40.363 \\
40.363\end{array}$ & $\begin{array}{r}1.191 \\
19.851 \\
60.214\end{array}$ \\
\hline Reliability (Cronbach's alpha) 0.700 & & \\
\hline
\end{tabular}

Table 11. EFA of the FA construct 
The last construct, satisfaction of the stakeholders (FSPP) was defined by seven variables which were all kept after just one analysis revealing the presence of two factors with eigenvalues exceeding 1 and $86.94 \%$ value of cumulative variation: "FSPPa: Financial result" representing the profit and loss account and "FSPPb: social result" measuring the impact of company and its activities on the different stakeholders' groups. The Cronbach's alpha was 0.889 .

\begin{tabular}{|l|r|r|}
\hline \multicolumn{1}{|c|}{ Variables } & \multicolumn{2}{c|}{ Rotated component matrix } \\
\cline { 2 - 3 } & $\begin{array}{c}\text { Financial result } \\
\text { (FSPPa) }\end{array}$ & $\mathbf{0 . 9 3 3}$ \\
(FSPPb)
\end{tabular}

Table 12. EFA of the FSPP construct

Each dimension found in this EFA has a value of reliability greater than 0.6, which is suggested by Malhotra (2004) as the minimum value that would be satisfactory to reliability measured. After this EFA analysis, confirmatory factory analysis (CFA) was performed to regroup variables on factors. These factors will correspond to our theoretical model.

\subsection{Confirmatory Factory Analysis}

Based on the result of EFA presented in Tables 4 through to 12, first-order CFA models were designed to test the multidimensionality and the factorial validity of the constructs of the theoretical framework (Byrne, 2001). The structural equation modeling software AMOS was used to perform the CFA.

To confirm the dimensionality of the scales, a priori specifications of the CFA model for a specific construct permitted the indicators to be freely loaded on their underlying factor(s) identified by the EFA, but limited them to having zero loadings on the remaining factor(s) within the construct (Byrne, 2001). The model was then evaluated by statistical means to determine the adequacy of its goodness to fit the sample data. The CFA was adapted to reducing the number of variables to improve the parsimony of the scale structure. As illustrate in Tables 4 to 12 , the constructs CO, FP, FS, FE, FA and FSPP was designed with two factors, while the constructs EP, FL and FO were designed with three factors derived from EFA. To begin the analysis, we use the underlying measurement variables derived from EFA linked to their corresponding factors for starting the process of evaluation. Then, during the model evaluation process, the statistical coefficients and fit indexes provided guidance for identifying possible candidate measurement variables for the final CFA models that represented adequate fit to the data (Chen, 2007). To have a good model, an evaluation on adequacy of the parameter estimates and overall model fit of the CFA models should be conducted for all the constructs. 
The fit of individual parameters presents three aspects, i.e. the feasibility of the parameter estimates; the appropriateness of the standard errors; and the statistical significance of the parameter estimates.

For the overall model fit of the CFA models, absolute (Chi-square, Probability level, RMR, GFI and AGFI), incremental (Normed Chi-square, NFI, CFI, IFI and TLI) and parsimonious (RMSEA, p close, AIC, BCC and ECVI) fit measures were considered.

So, in this study, if some fit tests are not respected, a specification of the model was considered and a new CFA analysis was conducted. The process continues until the satisfaction of all the fit measures.

After the evaluation of all successive CFA models for all the constructs, the final CFA models retained are given in Tables 13 through to 21 .

For the CO construct, the variables CO2 and CO5 were already removed by the EFA analysis and the other eight variables were kept for designing the initial CFA model. The likelihood ratio test revealed that the two-factor model yielded a chi square of 10.25 with a degree of freedom (d.f.) of 7 and a probability of 0.724 . An inspection of the modification indexes (MIs) related to the covariance showed clear evidence of misspecification associated with the variables CO3, CO4 and CO10. Byrne (2001: page 106) suggested that such measurement error covariance represent systematic, rather than random, measurement errors in item responses. For this, it was prudent to respecify the model without these three variables (Byrne, 2001: pages 106-117). The values of the absolute fit measures of the model, such as RMR $(0.048<0.05)$, GFI $(0.987>0.90)$ and AGFI (0.932), suggested a good fit (Byrne, 2001: page 82). The incremental fit measures values (the CFI (1), IFI (1.007) and TLI (1.014) were more than 0.95 , and the NFI value of 0.974 was more than 0.90 indicating a satisfactory fit to data (Byrne, 2001: page 83). The RMSEA value for the model was 0 , meaning a good fit. The AIC, BCC and ECVI values for the CFA model were between the independence and the saturated model values. These fit indexes suggested that this initial hypothesized model did fit the data fairly well (Byrne, 2001). Meanwhile, the analysis showed sound feasibility for the parameter estimates. The estimates were statistically different from zero at the level of 0.05 . In summary, the construct $\mathrm{CO}$ with two factors represents a fit to the data, and hence upheld the dimensionality of the scale.

\begin{tabular}{|c|c|c|c|c|c|}
\hline \multirow{2}{*}{$\begin{array}{l}\text { Factor and } \\
\text { measures } \\
\text { variable }\end{array}$} & \multirow{2}{*}{$\begin{array}{l}\text { EFA factor } \\
\text { loading }^{*}\end{array}$} & \multicolumn{3}{|c|}{ CFA } & \multirow[b]{2}{*}{ Final model of EP with standard estimation } \\
\hline & & $\mathrm{SMC}^{* *}$ & $\begin{array}{c}\text { Factor } \\
\text { loading }^{* * *}\end{array}$ & $\mathrm{CR}^{* * * *}$ & \\
\hline CO8 & 0.925 & 0.928 & 0.963 & 2.725 & \multirow{9}{*}{$\begin{array}{l}3^{, 61}-\operatorname{SMEAN}(\mathrm{CO} 1) \\
\mathrm{C}^{4}-\mathrm{SMEAN}(\mathrm{CO})\end{array}$} \\
\hline CO10 & 0.918 & \multicolumn{3}{|c|}{$\mathrm{n}$} & \\
\hline CO9 & 0.911 & 0.801 & 0.895 & 5.818 & \\
\hline $\mathrm{CO} 7$ & 0.877 & 0.824 & 0.908 & 5.494 & \\
\hline CO1 & 0.835 & 0.535 & 0.731 & 4.133 & \\
\hline $\mathrm{CO} 3$ & 0.822 & \multicolumn{3}{|c|}{$\mathrm{n}$} & \\
\hline CO6 & 0.691 & 0.663 & 0.814 & 2.695 & \\
\hline CO4 & 0.594 & \multicolumn{3}{|c|}{$\mathrm{n}$} & \\
\hline \multicolumn{5}{|c|}{$\begin{array}{l}\text { Notes: } \\
\text { *: Extraction method: principal component analysis; } \\
\text { Rotation method: Varimax with Kaiser normalization; } \\
\text { **: SMC: Squared multiple correlation (R2); } \\
\text { ***: Unstandardized estimates; } \\
\text { ****: Critical ratio (CR > 1.96: significant at } 0.05 \text { level). } \\
\text { n: Removed during model evaluation }\end{array}$} & \\
\hline
\end{tabular}

Table 13. EFA and CFA of the CO construct

For the second construct, EP (exigence of stakeholders), in the EFA, one variable EP3 was removed due to cross loadings and low factor loadings. Only nine variables were used in designing the initial CFA model for this 
construct. The likelihood ratio test revealed that the three-factor model yielded a chi square of 9.200 with a degree of freedom (d.f.) of 11 and a probability of 0.603 . An inspection of the modification indexes (MIs) related to the covariance showed clear evidence of misspecification associated with the EP2 and EP7. It was prudent to respecify the model without these two variables (Byrne, 2001: pages 106-117). The values of the absolute fit measures of the model, such as RMR $(0.047<0.05)$, GFI $(0.977>0.90)$ and AGFI $(0.942)$, suggested a good fit (Byrne, 2001: page 82). The incremental fit measures values (the CFI (1), IFI (1.007) and TLI (1.014)) were more than 0.95, and the NFI value of 0.964 was more than 0.90 indicated a satisfactory fit to data (Byrne, 2001: page 83). The RMSEA value for the model was 0 , meaning a good fit. The AIC, BCC and ECVI values for the CFA model were the independence and the saturated model values. These fit indexes suggested that this initial hypothesized model did fit the data fairly well (Byrne, 2001). Meanwhile, the analysis showed sound feasibility for the parameter estimates. The estimates were statistically different from zero at the level of 0.05. In summary, the construct EP with three factors represents a fit to the data, and hence upheld the dimensionality of the scale.

\begin{tabular}{|c|c|c|c|c|c|}
\hline \multirow{2}{*}{$\begin{array}{l}\text { Factor and } \\
\text { measures } \\
\text { variable }\end{array}$} & \multirow{2}{*}{$\begin{array}{l}\text { EFA factor } \\
\text { loading }\end{array}$} & \multicolumn{3}{|c|}{ CFA } & \multirow[b]{2}{*}{ Final model of EP with standard estimation } \\
\hline & & $\mathrm{SMC}^{* *}$ & $\begin{array}{c}\text { Factor } \\
\text { loading }\end{array}$ & $\mathrm{CR}^{* * * *}$ & \\
\hline EP5 & 0.898 & 0.771 & 0.878 & 3.783 & \multirow{10}{*}{$3-{ }_{3}^{75}-\operatorname{SMEAN(EP1)}$} \\
\hline EP10 & 0.897 & 0.724 & 0.851 & 4.523 & \\
\hline EP4 & 0.832 & 0.600 & 0.774 & 5.911 & \\
\hline EP2 & 0.793 & \multicolumn{3}{|c|}{$\mathrm{n}$} & \\
\hline EP6 & 0.791 & 0.350 & 0.592 & 4.989 & \\
\hline EP1 & 0.680 & 0.412 & 0.642 & 4.223 & \\
\hline EP7 & 0.581 & \multicolumn{3}{|c|}{ n } & \\
\hline EP9 & 0.831 & 0.263 & 0.513 & 5.935 & \\
\hline EP8 & 0.701 & 0.641 & 0.800 & 1.866 & \\
\hline \multicolumn{5}{|c|}{$\begin{array}{l}\text { Notes: } \\
\text { *: Extraction method: principal component analysis; } \\
\text { Rotation method: Varimax with Kaiser normalization; } \\
\text { **: SMC: Squared multiple correlation (R2); } \\
\text { ***: Unstandardized estimates; } \\
\text { ****: Critical ratio (CR > 1.96: significant at } 0.05 \text { level). } \\
\text { n: Removed during model evaluation }\end{array}$} & \\
\hline
\end{tabular}

Table 14. EFA and CFA of the EP construct

The third construct was FL (leadership function). In the EFA, one variable FL7 was removed due to cross loadings and low factor loadings, so the remaining nine variables were used in designing the initial CFA model. The likelihood ratio test revealed that the three-factor model yielded a chi square of 11.294, with a degree of freedom (d.f.) of 17 and a probability of 0.841 . An inspection of the modification indexes (MIs) related to the covariance showed clear evidence of misspecification associated with the FL10. So, the model was respecified without this variable (Byrne, 2001: pages 106-117). The values of the absolute fit measures of the model, such as RMR (0.037), GFI (0.978) and AGFI (0.935), suggested a good fit (Byrne, 2001: page 82). The incremental fit measures values (the CFI (1.000), IFI (1.029) and TLI (1.050) were more than 0.95, and the NFI value of 0.947 was more then 0.90 ) indicating a satisfactory fit to data (Byrne, 2001: page 83). The RMSEA value for the model was 0.00 meaning a good fit. These fit indexes suggested that this initial hypothesized model did fit the data fairly well (Byrne, 2001). In summary, the construct FL with three factors represents a fit to the data, and hence upheld the dimensionality of the scale. 


\begin{tabular}{|c|c|c|c|c|c|}
\hline \multirow{2}{*}{$\begin{array}{l}\text { Factor and } \\
\text { measures } \\
\text { variable }\end{array}$} & \multirow{2}{*}{$\begin{array}{l}\text { EFA factor } \\
\text { loading }\end{array}$} & \multicolumn{3}{|c|}{ CFA } & \multirow[b]{2}{*}{ Final model of FL with standard estimation } \\
\hline & & $\mathrm{SMC}^{* *}$ & $\begin{array}{c}\text { Factor } \\
\text { loading }^{* * *}\end{array}$ & $\mathbf{C R}^{* * * *}$ & \\
\hline FL9 & 0.877 & 0.579 & 0.761 & 3.617 & \multirow{10}{*}{$\begin{array}{l}\text { SMEAN(FL9) } \\
\text { SMEAN(FL8) }\end{array}$} \\
\hline FL8 & 0.833 & 0.701 & 0.837 & 2.303 & \\
\hline FL10 & 0.591 & \multicolumn{3}{|c|}{$\mathrm{n}$} & \\
\hline FL6 & 0.713 & 0.185 & 0.430 & 7.089 & \\
\hline FL2 & 0.707 & 0.253 & 0.503 & 6.887 & \\
\hline FL4 & 0.548 & 0.193 & 0.586 & 6.619 & \\
\hline FL5 & 0.546 & 0.416 & 0.842 & 3.942 & \\
\hline FL1 & 0.821 & 0.709 & 0.439 & 3.129 & \\
\hline FL3 & 0.530 & 0.344 & 0.645 & 6.566 & \\
\hline \multicolumn{5}{|c|}{$\begin{array}{l}\text { Notes: } \\
\text { *: Extraction method: principal component analysis; } \\
\text { Rotation method: Varimax with Kaiser normalization; } \\
\text { **: SMC: Squared multiple correlation (R2); } \\
\text { ***: Unstandardized estimates; } \\
\text { ****: Critical ratio (CR > 1.96: significant at } 0.05 \text { level). } \\
\text { n: Removed during model evaluation }\end{array}$} & \\
\hline
\end{tabular}

Table 15. EFA and CFA of the FL construct

During the EFA analysis of FP construct, one variable, FP6, was removed; and so, only five variables were used in designing the initial CFA model for this construct. The likelihood ratio test revealed that the two-factor model yielded a chi square of 5.697, with a degree of freedom (d.f.) of 4 and a probability of 0.223 . An inspection of the modification indexes (MIs) related to the covariance showed clear evidence of none misspecification associated. So, the five variables were kept in the analysis. The values of the absolute fit measures (RMR (0.035), GFI (0.981), AGFI (0.927)) and incremental fit measures (CFI (0.984) IFI (0.960), TLI (0.984) and the NFI (0.951)) of the model indicated a satisfactory fit to data (Byrne, 2001: page 83). The RMSEA value for the model was 0.061 meaning a good fit. With these fit indexes, we suggested that the construct FP with two factors represents a fit to the data, and hence upheld the dimensionality of the scale.

\begin{tabular}{|c|c|c|c|c|c|}
\hline \multirow{2}{*}{$\begin{array}{c}\text { Factor and } \\
\text { measures } \\
\text { variable }\end{array}$} & \multirow{2}{*}{$\begin{array}{l}\text { EFA factor } \\
\text { loading }\end{array}$} & \multicolumn{3}{|c|}{ CFA } & \multirow[b]{2}{*}{ Final model of FL with standard estimation } \\
\hline & & $\mathrm{SMC}^{* *}$ & $\begin{array}{c}\text { Factor } \\
\text { loading }^{* * *}\end{array}$ & $\mathbf{C R}^{* * * *}$ & \\
\hline FP2 & 0.836 & 0.237 & 0.487 & 6.635 & \multirow{6}{*}{$\begin{array}{l}\text { ST } \\
\text { SMEAN(FP2) }\end{array}$} \\
\hline FP3 & 0.731 & 0.308 & 0.555 & 5.902 & \\
\hline FP4 & 0.640 & 0.709 & 0.842 & 2.076 & \\
\hline FP1 & 0.849 & 0.328 & 0.573 & 5.602 & \\
\hline FP5 & 0.819 & 0.741 & 0.861 & 1.402 & \\
\hline \multicolumn{5}{|c|}{$\begin{array}{l}\text { Notes: } \\
\text { *: Extraction method: principal component analysis; } \\
\text { Rotation method: Varimax with Kaiser normalization; } \\
\text { **: SMC: Squared multiple correlation (R2); } \\
\text { ***: Unstandardised estimates; } \\
\text { ****: Critical ratio (CR > 1.96: significant at } 0.05 \text { level). } \\
\text { n: Removed during model evaluation }\end{array}$} & \\
\hline
\end{tabular}

Table 16. EFA and CFA of the FP construct 
For the FS construct, two variables (FS1, FS4) were already removed, during EFA analysis and so, only eight variables were kept for designing the initial CFA model. The likelihood ratio test revealed that the two-factor model yielded a chi square of 0.061 , with a degree of freedom (d.f.) of 1 and a probability of 0.804 . Because of the presence of a misspecification due to modification indexes (MIs) the variables FS2, FS3, FS9 and FS10 were removed and a respecification of the model was done using the remaining. The values of the absolute fit measures of the model, such as RMR (0.004<0.05), GFI (1.000) and AGFI (0.997) suggested a good fit. The incremental fit measures values (the CFI (1), IFI (1.005) and TLI (1.032) were more than 0.95, the NFI value of 1 was close to 0.90 and the RMSEA value for the model was 0.00 indicating a satisfactory fit to data. The AIC, BCC and ECVI values for the CFA model were between the independence and the saturated model values. These fit indexes suggested that this initial hypothesized model did fit the data fairly well.

\begin{tabular}{|c|c|c|c|c|c|}
\hline \multirow{2}{*}{$\begin{array}{c}\text { Factor and } \\
\text { measures } \\
\text { variable }\end{array}$} & \multirow{2}{*}{$\begin{array}{l}\text { EFA factor } \\
\text { loading }\end{array}$} & \multicolumn{3}{|c|}{ CFA } & \multirow[b]{2}{*}{ Final model of FL with standard estimation } \\
\hline & & $\mathrm{SMC}^{* *}$ & $\begin{array}{c}\text { Factor } \\
\text { loading*** }\end{array}$ & $\mathrm{CR}^{* * * *}$ & \\
\hline FS3 & 0.910 & \multicolumn{3}{|c|}{$\mathrm{n}$} & \multirow{9}{*}{ SMEAN(FS5) } \\
\hline FS2 & 0.888 & \multicolumn{3}{|c|}{$\mathrm{n}$} & \\
\hline FS5 & 0.786 & 0.821 & 0.906 & 2.130 & \\
\hline FS6 & 0.722 & 0.681 & 0.825 & 4.028 & \\
\hline FS8 & 0.877 & 0.409 & 0.640 & 5.863 & \\
\hline FS9 & 0.842 & \multicolumn{3}{|c|}{$\mathrm{n}$} & \\
\hline FS10 & 0.802 & \multicolumn{3}{|c|}{$\mathrm{n}$} & \\
\hline FS7 & 0.744 & 0.685 & 0.828 & 2.761 & \\
\hline \multicolumn{5}{|c|}{$\begin{array}{l}\text { Notes: } \\
\text { *: Extraction method: principal component analysis; } \\
\text { Rotation method: Varimax with Kaiser normalization; } \\
\text { **: SMC: Squared multiple correlation (R2); } \\
\text { ***: Unstandardized estimates; } \\
\text { ****: Critical ratio (CR > 1.96: significant at } 0.05 \text { level). } \\
\text { n: Removed during model evaluation }\end{array}$} & \\
\hline
\end{tabular}

Table 17. EFA and CFA of the FS construct

For the FO construct, the variables FO3, FO12 and FO13 were removed by the EFA analysis and the variables FO4, FO6, FO7 and FO9 were removed due to their associated misspecification. The likelihood ratio test revealed that the five-factor model yielded a chi square of 17.661, with a degree of freedom (d.f.) of 17 and a probability of 0.411. The values of the absolute fit measures (RMR (0.007), GFI (0.964), AGFI (0.924)), the incremental fit measures (CFI (0.998), IFI (0.998), TLI (0.997), NFI (0.953) and the parsimonious fit measures (RMSEA (0.018) of the model, all indicated a satisfactory fit to data (Byrne, 2001: page 83). The AIC, BCC and ECVI values for the CFA model were between the independence and the saturated model values. These fit indexes suggested that this initial hypothesized model did fit the data fairly well (Byrne, 2001).

The initial five variables of the FE construct were used in the CFA analysis, since no variable was removed from the EFA analysis. The likelihood ratio test revealed that the two-factor model yielded a chi square of 0.974 , with a degree of freedom (d.f.) of 4 and a probability of 0.914. An inspection of the modification indexes (MIs) related to the covariance showed none evidence of misspecification All the values of the fit measures of the model, absolute (RMR (0.023), GFI (0.997), AGFI (0.980)), incremental (CFI (1), IFI (1.014), TLI (1.035)) and parsimonious (RMSEA (0.00)) indicated a satisfactory fit to data (Byrne, 2001: page 83). The AIC, BCC and ECVI values for the CFA model were between the independence and the saturated model values. These fit indexes suggested that this initial hypothesized model did fit the data fairly well (Byrne, 2001). 


\begin{tabular}{|c|c|c|c|c|c|}
\hline \multirow{2}{*}{$\begin{array}{l}\text { Factor and } \\
\text { measures } \\
\text { variable }\end{array}$} & \multirow{2}{*}{$\begin{array}{l}\text { EFA factor } \\
\text { loading }\end{array}$} & \multicolumn{3}{|c|}{ CFA } & \multirow[b]{2}{*}{ Final model of FL with standard estimation } \\
\hline & & $\mathrm{SMC}^{* *}$ & $\begin{array}{c}\text { Factor } \\
\text { loading }\end{array}$ & $\mathrm{CR}^{* * * *}$ & \\
\hline FO7 & 0.856 & \multicolumn{3}{|c|}{$\mathrm{n}$} & \multirow{13}{*}{$3 \stackrel{1}{-09} \operatorname{SMEAN(FO8)}$} \\
\hline FO8 & 0.846 & 0.945 & 0.972 & 0.445 & \\
\hline FO10 & 0.825 & 0.705 & 0.839 & 2.960 & \\
\hline FO9 & 0.764 & & $\mathrm{n}$ & & \\
\hline FO1 & 0.832 & 0.696 & 0.834 & 2.848 & \\
\hline FO5 & 0.755 & 0.595 & 0.771 & 4.063 & \\
\hline FO6 & 0.632 & & & & \\
\hline $\mathrm{FO} 2$ & 0.600 & 0.192 & 0.438 & 7.068 & \\
\hline FO4 & 0.556 & & $\mathrm{n}$ & & \\
\hline FO11 & 0.862 & 0.698 & 0.835 & 3.657 & \\
\hline FO15 & 0.858 & 0.625 & 0.791 & 4.562 & \\
\hline FO14 & 0.812 & 0.512 & 0.716 & 5.845 & \\
\hline \multicolumn{5}{|c|}{$\begin{array}{l}\text { Notes: } \\
\text { *: Extraction method: principal component analysis; } \\
\text { Rotation method: Varimax with Kaiser normalization; } \\
\text { **: SMC: Squared multiple correlation (R2); } \\
\text { ***: Unstandardized estimates; } \\
\text { ****: Critical ratio (CR > 1.96: significant at } 0.05 \text { level). } \\
\text { n: Removed during model evaluation }\end{array}$} & \\
\hline
\end{tabular}

Table 18. EFA and CFA of the FO construct

\begin{tabular}{|c|c|c|c|c|c|}
\hline \multirow{2}{*}{$\begin{array}{l}\text { Factor and } \\
\text { measures } \\
\text { variable }\end{array}$} & \multirow{2}{*}{$\begin{array}{l}\text { EFA factor } \\
\text { loading }\end{array}$} & \multicolumn{3}{|c|}{ CFA } & \multirow[b]{2}{*}{ Final model of FL with standard estimation } \\
\hline & & $\mathrm{SMC}^{* *}$ & $\begin{array}{c}\text { Factor } \\
\text { loading }^{* * *}\end{array}$ & $\mathrm{CR}^{* * * *}$ & \\
\hline FE2 & 0.934 & 1.081 & 1.040 & -0.913 & \multirow{6}{*}{ STI-14) SMEAN(FE1) } \\
\hline FE3 & 0.872 & 0.581 & 0.762 & 5.747 & \\
\hline FE1 & 0.816 & 0.426 & 0.652 & 6.873 & \\
\hline FE4 & 0.861 & 0.654 & 0.809 & 1.040 & \\
\hline FE5 & 0.860 & 0.377 & 0.614 & 3.005 & \\
\hline \multicolumn{5}{|c|}{$\begin{array}{l}\text { Notes: } \\
\text { *: Extraction method: principal component analysis; } \\
\text { Rotation method: Varimax with Kaiser normalization; } \\
\text { **: SMC: Squared multiple correlation (R2); } \\
\text { ***: Unstandardised estimates; } \\
\text { ****: Critical ratio (CR > 1.96: significant at } 0.05 \text { level). } \\
\text { n: Removed during model evaluation }\end{array}$} & \\
\hline
\end{tabular}

Table 19. EFA and CFA of the FE construct

After performing an EFA and CFA analyses, two variables, FA3 and FA6, were removed. The remaining four variables were used in the subsequent CFA analysis, and the likelihood ratio test revealed that the five-factor model yielded a chi square of 1.691, with a degree of freedom (d.f.) of 1 and a probability of 0.193 . All the values of the fit measures of the model, such as absolute (RMR (0.024), GFI (0.993), AGFI (0.927)), incremental (CFI (0.993), IFI (0.993), TLI (0.958)) and parsimonious (RMSEA (0.078), suggested a good fit (Byrne, 2001: page 82). The AIC, BCC and ECVI values for the CFA model were between the independence and the saturated model values. These fit indexes suggested that this initial hypothesized model did fit the data fairly well (Byrne, 2001). 


\begin{tabular}{|c|c|c|c|c|c|}
\hline \multirow{2}{*}{$\begin{array}{l}\text { Factor and } \\
\text { measures } \\
\text { variable }\end{array}$} & \multirow{2}{*}{$\begin{array}{l}\text { EFA factor } \\
\text { loading }\end{array}$} & \multicolumn{3}{|c|}{ CFA } & \multirow[b]{2}{*}{ Final model of FL with standard estimation } \\
\hline & & $\mathrm{SMC}^{* *}$ & $\begin{array}{c}\text { Factor } \\
\text { loading }\end{array}$ & $\mathbf{C R}^{* * * *}$ & \\
\hline FA4 & 0.907 & 0.715 & 0.846 & 1.259 & \multirow[b]{7}{*}{.28} \\
\hline FA5 & 0.835 & 0.593 & 0.770 & 2.113 & \\
\hline FA3 & 0.568 & \multicolumn{3}{|c|}{$\mathrm{n}$} & \\
\hline FA2 & 0.791 & 0.384 & 0.620 & 3.414 & \\
\hline FA1 & 0.784 & 0.602 & 0.776 & 1.545 & \\
\hline FA6 & 0.607 & & $\mathrm{n}$ & & \\
\hline \multicolumn{5}{|c|}{$\begin{array}{l}\text { Notes: } \\
\text { *: Extraction method: principal component analysis; } \\
\text { Rotation method: Varimax with Kaiser normalization; } \\
\text { **: SMC: Squared multiple correlation (R2); } \\
\text { ***: Unstandardised estimates; } \\
\text { ****: Critical ratio (CR > 1.96: significant at } 0.05 \text { level). } \\
\text { n: Removed during model evaluation }\end{array}$} & \\
\hline
\end{tabular}

Table 20. EFA and CFA of the FA construct

In the last FSPP construct, only four variables were kept for the final CFA analysis, the FSPP2, FSPP3 and FSPP7 were removed. The proposed two-factor model yielded a chi square of 0.663 , with a degree of freedom (d.f.) of 4 and a probability of 0.956 . All the values of the fit measures of the model, such as absolute (RMR (0.027), GFI (0.998), AGFI (0.991)), incremental (CFI (1), IFI (1.032), TLI (1.084)) and parsimonious (RMSEA (0.00)), suggested a good fit.

\begin{tabular}{|c|c|c|c|c|c|}
\hline \multirow{2}{*}{$\begin{array}{l}\text { Factor and } \\
\text { measures } \\
\text { variable }\end{array}$} & \multirow{2}{*}{$\begin{array}{l}\text { EFA factor } \\
\text { loading }\end{array}$} & \multicolumn{3}{|c|}{ CFA } & \multirow[b]{2}{*}{ Final model of FL with standard estimation } \\
\hline & & $\mathrm{SMC}^{* *}$ & $\begin{array}{c}\text { Factor } \\
\text { loading }^{* * *}\end{array}$ & $\mathbf{C R}^{* * * *}$ & \\
\hline FSPP2 & 0.933 & \multicolumn{3}{|c|}{$\mathrm{n}$} & \multirow{8}{*}{ (2) } \\
\hline FSPP7 & 0.932 & \multicolumn{3}{|c|}{$\mathrm{n}$} & \\
\hline FSPP1 & 0.929 & 1.134 & 1.065 & -0.507 & \\
\hline FSPP5 & 0.870 & 0.522 & 0.722 & 3.498 & \\
\hline FSPP4 & 0.943 & 0.939 & 0.969 & 0.596 & \\
\hline FSPP6 & 0.923 & 0.829 & 0.911 & 1.637 & \\
\hline FSPP3 & 0.872 & \multicolumn{3}{|c|}{$\mathrm{n}$} & \\
\hline \multicolumn{5}{|c|}{$\begin{array}{l}\text { Notes: *: Extraction method: principal component analysis; } \\
\text { Rotation method: Varimax with Kaiser normalization; } \\
\text { **: SMC: Squared multiple correlation (R2); } \\
\text { ***: Unstandardised estimates; } \\
\text { ****: Critical ratio (CR > 1.96: significant at } 0.05 \text { level). } \\
\text { n: Removed during model evaluation }\end{array}$} & \\
\hline
\end{tabular}

Table 21. EFA and CFA of the FSPP construct

\subsection{Regression and Correlation Analysis}

Based on the results of the EFA and CFA analyses, we conducted a correlation and regression analyses. The correlation analysis was employed to envisage the relationship between the constructs of the theoretical framework while the regression analysis measured the degree of influence of each factor. We used the Pearson productmoment correlation technique to determine the extent to which the variables were linearly related (Jaccard \& Becker, 1997: page 126). The analysis showed that all nine constructs are positively associated with one another, as are their factors. 
Where, the correlation analysis showed that the constructs are relatively positively correlated to each other; a regression analysis was, then elaborated for measuring the degree of influence of each construct on the others. To pursue the stepwise analysis, specific dependent variables were hypothesized as being influenced by a set of independent variables. The independent variable which had a strong correlation with a dependent variable was entered in regression model. We selected the variable which had an adjusted $\mathrm{R}^{2}$ (the multiple coefficient of determination) over then 0.2 . An Adj. $\mathrm{R}^{2}$ value indicates the percentage of total variance of a criterion explained by predictor/s in a regression model (Hair et al., 1998: page 156).

The results given in Table 22 were significant and values ranged from 0.221 to 0.705 .

In general, the obtained results revealed a very interesting relationship between the different factors. The CO and EP are combined with $40.1 \%$; the variables EP and FL with $24.8 \%, 46.5 \%$ and $22.1 \%$; the variables FL and FP with $54.4 \%$ and $38.5 \%$; the variables FL and FS with $41.1 \%$ and $32.1 \%$; the variables FS and FO with $56.3 \%$, $46.1 \%$ and $29.4 \%$; the variables FO and FE $23 \%, 34.1 \%$ and $37.5 \%$; the variables FE and FA with $28.3 \%$ and $26.3 \%$; and finally, the variables FA and FSPP with $23.3 \%$ and $70.5 \%$. The results of regression are shown in Table 22, and the final proposed model with all the relationships defined between the factors is given in Figure 3.

\begin{tabular}{|c|c|c|c|c|}
\hline $\begin{array}{l}\text { Independent } \\
\text { variable }\end{array}$ & $\begin{array}{l}\text { Dependent } \\
\text { variable }\end{array}$ & $\mathbf{R}$ & $\mathbf{R}^{2}$ & $\mathbf{R}^{2 \cdot}$ Adj. \\
\hline Cob & $\begin{array}{l}\mathrm{COa} \\
\mathrm{EPa} \\
\mathrm{FLb}\end{array}$ & $\begin{array}{l}0.480 \\
0.638 \\
0.615\end{array}$ & $\begin{array}{l}0.231 \\
0.407 \\
0.378\end{array}$ & $\begin{array}{l}0.224 \\
0.401 \\
0.372\end{array}$ \\
\hline$(\mathrm{EPa})$ & $\begin{array}{l}(\mathrm{FLc}) \\
(\mathrm{FLb}) \\
\text { FLa })\end{array}$ & $\begin{array}{l}0.505 \\
0.685 \\
0.478\end{array}$ & $\begin{array}{l}0.255 \\
0.469 \\
0.228\end{array}$ & $\begin{array}{l}0.248 \\
0.465 \\
0.221\end{array}$ \\
\hline (FLb) & $(\mathrm{FPb})$ & 0.740 & 0.548 & 0.544 \\
\hline (FLa) & $(\mathrm{FPa})$ & 0.625 & 0.390 & 0.385 \\
\hline$(\mathrm{FPa})$ & $\begin{array}{l}(\mathrm{FSa}) \\
(\mathrm{FSb})\end{array}$ & $\begin{array}{l}0.204 \\
0.250\end{array}$ & $\begin{array}{l}0.042 \\
0.062\end{array}$ & $\begin{array}{l}0.033 \\
0.054\end{array}$ \\
\hline$(\mathrm{FPb})$ & $\begin{array}{l}(\mathrm{FSa}) \\
(\mathrm{FSb})\end{array}$ & $\begin{array}{l}0.651 \\
0.572 \\
\end{array}$ & $\begin{array}{l}0.423 \\
0.327 \\
\end{array}$ & $\begin{array}{l}0.418 \\
0.321 \\
\end{array}$ \\
\hline (FSa) & $\begin{array}{l}\mathrm{FOa}) \\
\mathrm{FOb})\end{array}$ & $\begin{array}{l}0.753 \\
0.682 \\
\end{array}$ & $\begin{array}{l}0.567 \\
0.465\end{array}$ & $\begin{array}{l}0.563 \\
0.461 \\
\end{array}$ \\
\hline (FOc) & $(\mathrm{FEb})$ & 0.589 & 0.347 & 0.341 \\
\hline FOa & $\begin{array}{l}\mathrm{FEa} \\
\mathrm{FEb}\end{array}$ & $\begin{array}{l}0.307 \\
0.407\end{array}$ & $\begin{array}{l}0.094 \\
0.162\end{array}$ & $\begin{array}{l}0.086 \\
0.155\end{array}$ \\
\hline FEa & FAa & 0.538 & 0.289 & 0.283 \\
\hline FEb & $\mathrm{FAb}$ & 0.522 & 0.273 & 0.266 \\
\hline FAb & $\begin{array}{l}\text { FSPPb } \\
\text { FSPPa }\end{array}$ & $\begin{array}{l}0.841 \\
0.490\end{array}$ & $\begin{array}{l}0.707 \\
0.240\end{array}$ & $\begin{array}{l}0.705 \\
0.233\end{array}$ \\
\hline FAa & $\begin{array}{l}\text { FSPPb } \\
\text { FSPPa }\end{array}$ & $\begin{array}{l}0.214 \\
0.287\end{array}$ & $\begin{array}{l}0.046 \\
0.077\end{array}$ & $\begin{array}{l}0.035 \\
0.067\end{array}$ \\
\hline
\end{tabular}

Table 22. Stepwise regression analysis with all process of IMS

Finally, from all these analyses, we can say that external issues are more important than the internal ones. Companies have an internal difficulty of organization due the lack of motivation of the employees and lack of internal organizational culture as already found by Simon et al. (2012) and Gianni and Gotzamani (2015). The companies tested are most interested in external issues and not in their employees' requirements. We can also note that they have some difficulty in integrating systems due to the lack of integration guidelines and management commitment (Gianni \& Gotzamani, 2015). Besides, the planning phase is most done based on the client needs (Bernardo \& Casadesus, 2009), while the risks are totally ignored in the plan. The operational processes in 
production and design of production are strongly related $(0.563,0.461)$ to the policy used toward the awareness of employee while the release of production is related (0.294) to the information system itself. For the performance evaluation, the monitoring and measuring systems adopted by the companies for the level of customer satisfaction or for the product/service itself is used moderately (0.230) only at the design of the production phase, while the audit and the management review is used moderately (0.341) only after the release of the product. The nonconformity is moderately $(0.283)$ treated after the measurement and the monitoring process while the continuous improvement is positively and moderately linked (0.266) to the audit process. Finally, the growth in rate of productivity and the image of the company are positively and very strongly linked (0.705) to the continuous improvement while the value added and the improving product/service quality are positively and moderately linked (0.233) to the continuous improvement this result is in accordance with the finding of López-Fresno, 2010. In general, the management of the non-conforming products has no interest for most of the companies contacted.

We conclude that the integration of multiple management systems has just settled in Algerian companies. The results show that most companies have many difficulties when integrating multiple management systems for this, some factors were eliminated.

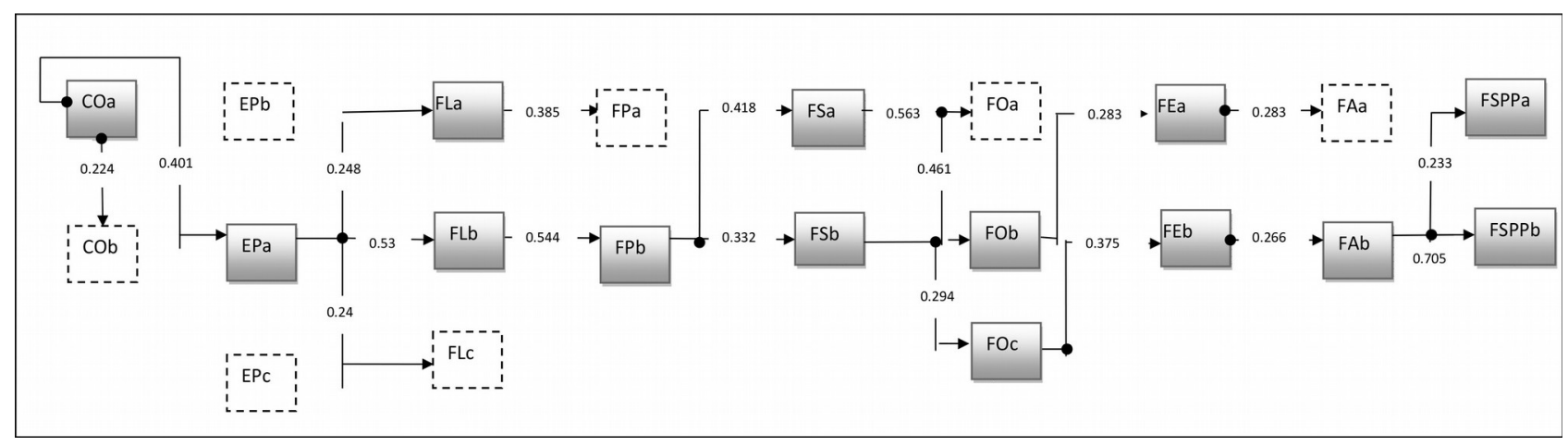

Figure 3. Relationship with factor of process

\section{Conclusion}

The concept of integrated management system is, actually, emerged in the organization management. It is a set of related processes that share information about human, financial and infrastructural resources in order to achieve preset objectives, while focusing on the requirements of all stakeholders.

Algerian companies, as other organization in the world, are seeking new approach for improving their competitiveness to face change in environment. Today, the implementation of many standards is a very big, as the performance of the companies depends on it. However, these organizations have difficult to manage multiple standards with different procedures and documentations, adopting the IMS was the only way to face this challenge.

The objective of the present work was to empirically test a theoretical proposed model based on a functional analysis of the systemic approach for the integrated management. The system chosen is based on a structure of seven (07) items. In order to have a harmonious system, some relationships are assumed to exist between these functions, in order to increase the intensity of the process and also to produce more value. These relationships are analyzed by the APTE method, which allows defining the system, in its basic and sub functions which are related to the delivery of the product/service, and especially to meet the stakeholders' requirements which the system must satisfy. The proposed model provides a global overview on the functioning of the Integrated Management System (IMS) and aims to simplify the reading and understanding of different standards by those interested managers; and allows them to integrate different management systems in a unique one, without great difficulty.

In general, the seven supposed hypotheses were supported, in somehow, by the correlation and regression analyses. To define the requirements, the results obtained showed that the Algerian companies are more interested in external issues, rather the internal ones with the employees' requirements, and from all the interested parties, the client is the only interested person in defining the needs. Companies have an internal difficulty of organization due the lack of 
motivation of the employees and lack of internal organizational culture. Also, the management of risks is totally absent in the strategy of the companies while the management of non-conformity is not a priority task for them. The results showed also a lack of top management involvement (no correlation between the FPa sub function and the FS), a result supported by the finding Abad et al., 2016. Finally, the continuous improvement is more defined by the growth in rate of productivity and the image of the company rather than by the value added and the improving product/service quality.

We conclude that the integration of multiple management systems has just settled in Algerian companies. The results show that most companies have many difficulties when integrating multiple management systems. The proposed model provides a baseline and insight into future use of HLS principle so as to improve the performance. It allows a good implementation of IMS in Algerian companies in order to help them to remain competitive in an increasingly complex environment.

In a general context, this study will contribute to the existing certified management systems by introducing a strategic IMS process theoretical framework, which is strongly supported by the empirical evidence. The proposed model indicates that the seven requirements have a direct impact on the performance of a company and may help all the companies that have already adopted more than one management system to reduce the amount of the documented information and achieve preset objectives while respecting the requirements of all the stakeholders.

Finally, although we obtained useful results, some limitations may be inherent in this research, such as the resources available where the study was limited to a relatively small sample size and a small sample diversity in terms of sectors and type of integration used.

\section{Acknowledgements}

The authors would like to acknowledge the support and assistance of all the participating organizations and specially their top managers who responded to the questionnaires and made this research study possible.

\section{Declaration of Conflicting Interests}

The authors declared no potential conflicts of interest with respect to the research, authorship, and/or publication of this article.

\section{Funding}

The authors received no financial support for the research, authorship, and/or publication of this article.

\section{References}

Abad, J., Cabrera, H.R., \& Medina, A. (2016). An analysis of the perceived difficulties arising during the process of integrating management systems. Journal of Industrial Engineering and Management, 9(3), 860-878.

https://doi.org/10.3926/jiem.1989

Ahsen, A. Von, \& Funck, D. (2001). Integrated Management Systems - Opportunities and Risks for Corporate Environmental Protection. Corporate Environmental Strategy, 8(2), 165-176. https://doi.org/10.1016/S10667938(01)00089-6

Almeida, J., Domingues, P., \& Sampaio, P. (2014). Different perspectives on management systems integration. Total Quality Management \&o Business Excellence, 25, 338-351. https://doi.org/10.1080/14783363.2013.867098

Amarah, B. (2015). Development of a Triple Bottom Line Stakeholder Satisfaction Model. Queensland Australia: Faculty of Society \& Design Bond University Gold Coast.

Asif, M., de Bruijn, E.J., Fisscher, O.A.M., Searcy, C., \& Steenhuis, H-J. (2009). Process embedded design of integrated management systems. The International Journal of Quality \& Reliability Management, 26(3), $261-282$. https://doi.org/10.1108/02656710910936735

Asif, M., Fisscher, O.A.M., de Bruijn, E., \& Pagell, M. (2010). An examination of strategies employed for the integration of management systems. The TQM Journal, 22(6), 648-669. https://doi.org/10.1108/17542731011085320 
Beckmerhagen, I.A., Berg, H.P., Karapetrovic, S.V., \& Wilborn, W.O. (2003). Integration of management systems: Focus on safety in the nuclear industry. International Journal of Quality \& Reliability Management, 20(2), 210-228. https://doi.org/10.1108/02656710310456626

Bernardo, M., \& Casadesus, M. (2009). How integrated are environmental, quality and other standardized management systems? An empirical study. Journal of Cleaner Production. Available at: https://www.sciencedirect.com/science/article/pii/S0959652608002813 https://doi.org/10.1016/j.jclepro.2008.11.003

Bernardo, M., Gotzamani, K., Vouzas, F., \& Casadesus, M. (2016). A qualitative study on integrated management systems in a non-leading country in certifications. Total Quality Management \& Business Excellence, 3363(July), 1-28. https://doi.org/10.1080/14783363.2016.1212652

Bhuiyan, N., \& Baghel, A. (2005). An overview of continuous improvement: from the past to the present, 43(5), 761-771. https://doi.org/10.1108/00251740510597761

Byrne, B.M. (2001). Structual Equation Modeling with AMOS, Basic Concepts, Applications and Programming,. London: Lawrence Erlbaum Associates, Ed.

Chen, L.E. (2007). Linking Knowledge Management to Organisational Business Performance in Construction. Thesis (PhD Doctorate). Griffith University, Brisbane

Dahlin, G., \& Isaksson, R. (2017). Integrated management systems- interpretations, results, opportunities. The TQM Journal, 29(3), 528-542. https://doi.org/10.1108/TQM-01-2016-0004

Domingues, P., Sampaio, P., \& Arezes, P. M. (2017). Management systems integration: survey results. International Journal of Quality \& Reliability Management, 34(8), 1252-1294. https://doi.org/10.1108/IJQRM-03-2015-0032

Ezzat, A., Bahi, S., \& Nasreldeen, T. (2017). Towards Better Enviromental Performance: A Framework for IMS. International Journal of Scientific \& Engineering Research, 8(2), 105-130.

Garvin, D.A. (1991). How the Baldrige Award Really Works, Harvard Business Review 69, 6, 80-93.

Georgiev, S., \& Georgiev, E. (2015). Motivational Factors for the Adoption of ISO 9001 Standards in Eastern Europe: The Case of Bulgaria. Journal of Industrial Engineering and Management, 8(3), 1020-1050.

https://doi.org/10.3926/jiem.1355

Gianni, M., \& Gotzamani, K. (2015). Management systems integration: Lessons from an abandonment case. Journal of Cleaner Production, 86, 265-276. https://doi.org/10.1016/j.jclepro.2014.08.023

Gianni, M., Gotzamani, K., \& Vouzas, F. (2017). Food integrated management systems: dairy industry insights. International Journal of Quality \& Reliability Management, 34(2), 194-215. https://doi.org/10.1108/IJQRM-05-2015-0076

Hair, J.F., Anderson, R.E., Tatham, R.L., \& Black, W.C. (1998). Multivariate Data Analysis. Upper Saddle River, NJ: Prentice-Hall International, Inc.

Isaksson, R., \& Garvare, R. (2003). Measuring sustainable development using process models. Managerial Auditing Journal, 18(8), 649-656. https://doi.org/10.1108/02686900310495142

Jaccard, J., \& Becker, M.A. (1997). Statistics for the Behavioral Sciences. (A division of International Thomson Publishing Inc., Ed.). London: Brooks/Cole Publishing Company.

Kafel, P. (2016). Benefits of management systems integration. Studia Oeconomica Posnaniensia, 4(10). https://doi.org/10.18559/SOEP.2016.10.9

Karapetrovic, S. (2002). Strategies for the integration of management systems and standards. The TQM Magazine, 14(1), 61-67. https://doi.org/10.1108/09544780210414254

Karapetrovic, S., \& Jonker, J. (2003). Integration of standardized management systems: Searching for a recipe and ingredients. Total Quality Management \& Business Excellence, 14(4), 451-459.

https://doi.org/10.1080/1478336032000047264 
Khanna, K.H., Laroiya, S.C., \& Sharma, D.D. (2010). integrated management system in indian manifacturing organizations: some key from en empirical study. The TQM Journal, 22(6), 670-686.

https://doi.org/10.1108/17542731011085339

Kline, R.B. (1998). Principles and Practice of Structural Equation Modeling. New York: The Guilford Press.

López-Fresno, P. (2010). Implementation of an integrated management system in an airline: a case study. The TQM Journal, 22(6), 629-647. https://doi.org/10.1108/17542731011085311

Malhotra, N.K. (2004). Marketing research: An applied orientation (4th editio). L. Prentice-Hall International, Ed.

Mathé, J.C., \& Chagué, V. (1999). L'intention stratégique et les divers types de performance de l'entreprise. Revue française de Gestion, 122, 39-49.

Miguel, L., \& Martins, C. (2015). ISO 14001: 2015: An Improved Tool for Sustainability, Journal of Industrial Engineering and Management, 8(1), 37-50. https://doi.org/10.3926/jiem.1298

Moumen, M., \& El Aoufir, H. (2017). Quality, safety and environment management systems (QSE): Analysis of empirical studies on integrated management systems (IMS). Journal of Decision Systems, 26(3), $207-228$. https://doi.org/10.1080/12460125.2017.1305648

Muehlen, M. zur (2004). Workflow-based process controlling: Foundation, design, and application of workflow-driven process information systems. Logos Verlag.

Mustapha, M.A., Manan, Z.A., \& Wan Alwi, S.R. (2017). Sustainable Green Management System (SGMS) - An integrated approach towards organisational sustainability. Journal of Cleaner Production, 146, $158-172$. https://doi.org/10.1016/j.jclepro.2016.06.033

Olaru, M., Maier, D., Nicoară, D., \& Maier, A. (2014). Establishing the basis for Development of an Organization by Adopting the Integrated Management Systems: Comparative Study of Various Models and Concepts of Integration. Procedia - Social and Behavioral Sciences, 109, 693-697. https://doi.org/10.1016/j.sbspro.2013.12.531

Pallant, J. (2001). SPSS Survival Manual: a step by step guide to data analysis using SPSS for Windows. St Leonards, NSW: Allen \& Unwin.

Puvanasvaran, P., Tian, R.K.S., Suresh, V., \& Muhamad, M.R. (2012). Lean principles adoption in environmental management system (EMS): A survey on ISO 14001 certified companies in Malaysia. Journal of Industrial Engineering and Management, 5(2), 406-430. https://doi.org/10.3926/jiem.486

Rebelo, M.F., Santos, G., \& Silva, R. (2014a). A generic model for integration of Quality, Environment and Safety Management Systems. The TQM Journal, 26(2), 143-159. https://doi.org/10.1108/TQM-08-2012-0055

Rebelo, M.F., Santos, G., \& Silva, R. (2014b). Integration of Individualized Management Systems (MSs) as an Aggregating Factor of Sustainable Value for Organizations: An Overview Through a Review of. Journal of Modern Accounting and Auditing, 10(3), 356-383. Available at: http://www.davidpublishing.com/davidpublishing/Upfile/4/2/2014/2014040270547697.pdf

Rocha, M., Searcy, C., \& Karapetrovic, S. (2007). Integrating Sustainable Development into Existing Management Systems. Total Quality Management \& Business Excellence, 18(1-2), 83-92. https:/ / doi.org/10.1080/14783360601051594

Salomone, R. (2008). Integrated management systems: experiences in Italian organizations. Journal of Cleaner Production, 16(16), 1786-1806. https://doi.org/10.1016/j.jclepro.2007.12.003

Simon, A., Bernardo, M., Karapetrovic, S., \& Casadesús, M. (2011). Integration of standardized environmental and quality management systems audits. Journal of Cleaner Production, 19(17-18), 2057-2065.

https://doi.org/10.1016/j.jclepro.2011.06.028

Simon, A. (2012). An Empirical Analysis of Integrated Management Systems. Doctoral Thesis. University of Girona, Spain. 
Simon, A., Karapetrovic, S., \& Casadesús, M. (2012). Difficulties and benefits of integrated management systems. Industrial Management \& Data Systems, 112(5), 828-846. https://doi.org/10.1108/02635571211232406

Simon, A., Karapetrovic, S., \& Casadesús, M. (2014). Difficulties and benefits of integrated management systems. https://doi.org/10.1108/02635571211232406

Wilkinson, G., \& Dale, B.G. (2000). Management system standards: The key integration issues. Proceedings of the Institution of Mechanical Engineers, Part B: Journal of Engineering Manufacture, 214(9), 771-780.

https://doi.org/10.1243/0954405001517838

Willborn, W. (1998). Integration of quality and environmental management systems concepts Integration of quality and environmental. The TQM Magazine, 10(3), 204-213. https://doi.org/10.1108/09544789810214800

Zeng, S.X., Lou, G.X., \& Tam, V.W.Y. (2006). Integration of management systems: the views of contractors. Architectural Science Review, 49(3), 229-235. https://doi.org/10.3763/asre.2006.4931

Zeng, S.X., Shi, J.J., \& Lou, G.X. (2007). A synergetic model for implementing an integrated management system: an empirical study in China. Journal of Cleaner Production, 15(18), 1760-1767.

https://doi.org/10.1016/j.jclepro.2006.03.007

Journal of Industrial Engineering and Management, 2018 (www.jiem.org)

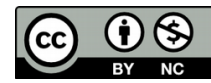

Article's contents are provided on an Attribution-Non Commercial 4.0 Creative commons International License. Readers are allowed to copy, distribute and communicate article's contents, provided the author's and Journal of Industrial Engineering and Management's names are included. It must not be used for commercial purposes. To see the complete license contents, please visit https://creativecommons.org/licenses/by-nc/4.0/. 